Research, part of a Special Feature on Long-term Vulnerability and Transformation

\title{
The Cross-scale Interplay between Social and Biophysical Context and the Vulnerability of Irrigation-dependent Societies: Archaeology's Long- term Perspective
}

\author{
$\underline{\text { Margaret C. Nelson }}^{1}, \underline{\text { Keith Kintigh }}^{1}, \underline{\text { David R. Abbott }}^{1}$, and John M. Anderies ${ }^{1}$
}

\begin{abstract}
What relationships can be understood between resilience and vulnerability in socialecological systems? In particular, what vulnerabilities are exacerbated or ameliorated by different sets of social practices associated with water management? These questions have been examined primarily through the study of contemporary or recent historic cases. Archaeology extends scientific observation beyond all social memory and can thus illuminate interactions occurring over centuries or millennia. We examined trade-offs of resilience and vulnerability in the changing social, technological, and environmental contexts of three long-term, pre-Hispanic sequences in the U.S. Southwest: the Mimbres area in southwestern New Mexico (AD 650-1450), the Zuni area in northern New Mexico (AD 850-1540), and the Hohokam area in central Arizona (AD 700-1450). In all three arid landscapes, people relied on agricultural systems that depended on physical and social infrastructure that diverted adequate water to agricultural soils. However, investments in infrastructure varied across the cases, as did local environmental conditions. Zuni farming employed a variety of small-scale water control strategies, including centuries of reliance on small runoff agricultural systems; Mimbres fields were primarily watered by small-scale canals feeding floodplain fields; and the Hohokam area had the largest canal system in pre-Hispanic North America. The cases also vary in their historical trajectories: at Zuni, population and resource use remained comparatively stable over centuries, extending into the historic period; in the Mimbres and Hohokam areas, there were major demographic and environmental transformations. Comparisons across these cases thus allow an understanding of factors that promote vulnerability and influence resilience in specific contexts.
\end{abstract}

Key Words: agriculture; infrastructure; irrigation; resilience; vulnerability; water

\section{INTRODUCTION}

In a recently published special issue of the Proceedings of the National Academy of Sciences, Ostrom et al. (2007) argue that single, overarching solutions to sustainability issues are doomed to failure because they are overly optimistic about the similarity in the characteristics of resource problems, preferences, information, and the actors across the many different contexts in which they might be applied. With respect to water institutions, Ruth Meinzen-Dick (2007:15200) argues, "Research that identifies the critical factors affecting irrigation institutions can lead to sustainable approaches that are adapted to specific contextual attributes." The key phrase here is "adapted to specific contextual attributes," highlighting the fact that panaceas or generalizations about how sustainability can be achieved fall short because of the variability in local social and environmental conditions. Although Meinzen-Dick and others in the Ostrom et al. (2007) special issue are typically referring to small-scale social-ecological systems (SESs) embedded in modern state-level systems, their insights apply broadly to water control systems used by agriculturalists. As they argue, context matters. Here, we examine the changing role of social context in the realization of the long-term performance of three SESs involving water management, with attention to the robustnessvulnerability trade-offs within such systems.

Important determinants of the performance of social-ecological systems include the biophysical 
context, e.g., topography, biogeochemistry, and ecology, and the infrastructure, e.g., physical capital, institutions, and social capital. Infrastructure in arid environments can be structured to cope with spatial and temporal variability in water availability and to increase productivity (Schlager et al. 1994, Janssen et al. 2007). Irrigation and storage infrastructure, for example, can promote resilience to specific kinds of environmental variation. However, they also anchor people to particular locations, foreclosing options such as mobility, and may generate new vulnerabilities to other social and environmental conditions (Anderies 2006, Janssen et al. 2007). Previous research by us and others using both modeling and archaeological data indicate that although irrigation systems may foster economies robust to short-term variation in precipitation, they may also contribute to vulnerabilities that sometimes lead to costly transformations (Abbott 2003a, Anderies 2006, Graybill et al. 2006, Hegmon et al. 2008, J. Howard 1993, 2006). A trade-off between vulnerability to short-term and long-term fluctuations is a fundamental property of a large class of simple dynamical systems (Bode 1945). This fundamental property implies that it is challenging to be simultaneously robust to fluctuations that occur with an annual frequency and to those that occur once every 50 years.

Here, we explore the trade-offs in robustness and vulnerability in three pre-Hispanic cultural sequences dating from AD 650 to 1540 in the U.S. Southwest, all of which are agricultural societies dependent on water management (Fig. 1): the Mimbres area in southwestern New Mexico (AD 650-1300), the Zuni area in northern New Mexico (AD 850-1540), and the Hohokam area in central Arizona (AD 700-1450). By comparing these cases, we can evaluate, over the long term, how the different physical and social infrastructural contexts affected the persistence of farming societies. The cases share key features: they are located in similarly arid landscapes in which dryland agriculture is tenuous to impossible; all have similar cropping systems and crop mixes that rely on maize; and all of these agricultural systems depended on physical and social infrastructure that concentrated water on agricultural soils. However, on close inspection, they are quite different in ways that are important to understanding the persistence or transformation of different aspects of these socialecological systems. Across the cases, investments in infrastructure varied, as did local environmental conditions. Zuni farming employed a variety of small-scale water control strategies, including centuries of reliance on small run-off agricultural systems; Mimbres fields were primarily watered by small-scale canals feeding floodplain fields; the Hohokam area had the largest canal systems in preHispanic North America. The cases also vary in their historical trajectories. At Zuni, population and resource use remained comparatively stable over centuries, extending into the historic period, whereas the Mimbres and Hohokam areas experienced major demographic and environmental transformations. For these three cases, we explore how changing social and environmental contexts influenced the realization of different vulnerabilities as evidenced in large-scale social-ecological transformations.

We acknowledge that archaeological interpretations are coarse-grained and sensitive to the vagaries of preservation and the design of sampling. The histories summarized here are based on our understanding of the data now available, but can be expected to change as the scope and diversity of data expand. Although we cannot directly "observe" institutions and practices of the past, we can make informed inferences about them from material remains. Of course, some of these inferences are disputed, and we attempt to reference key disputed points. We note that interpretations of modern observations are also frequently contested.

\section{RESILIENCE, ROBUSTNESS, AND VULNERABILITY}

Our comparative analysis is driven by key aspects of resilience theory. We note that resilience theory is not a collection of ideas intended to explain the behavior of SESs (Anderies et al. 2006), but "is a broad, multifaceted, and loosely organized cluster of concepts, each one related to some aspect of the interplay of transformation and persistence" (Carpenter and Brock 2008). When used to describe a SES, rather than a theory, resilience refers to the capacity of a system to cope with shocks and maintain its structure and function, self-organize, and foster learning (see www.resalliance.org). Our comparative study focuses on how human actions directed at influencing the capacity of a SES to cope with particular shocks affect the interplay between transformation and persistence in three specific instances. To explore this relationship, we employ a framework emphasizing robustness-vulnerability trade-offs (Anderies et al. 2007). Whereas resilience 
Fig. 1. The location of the case studies in the U.S. Southwest.

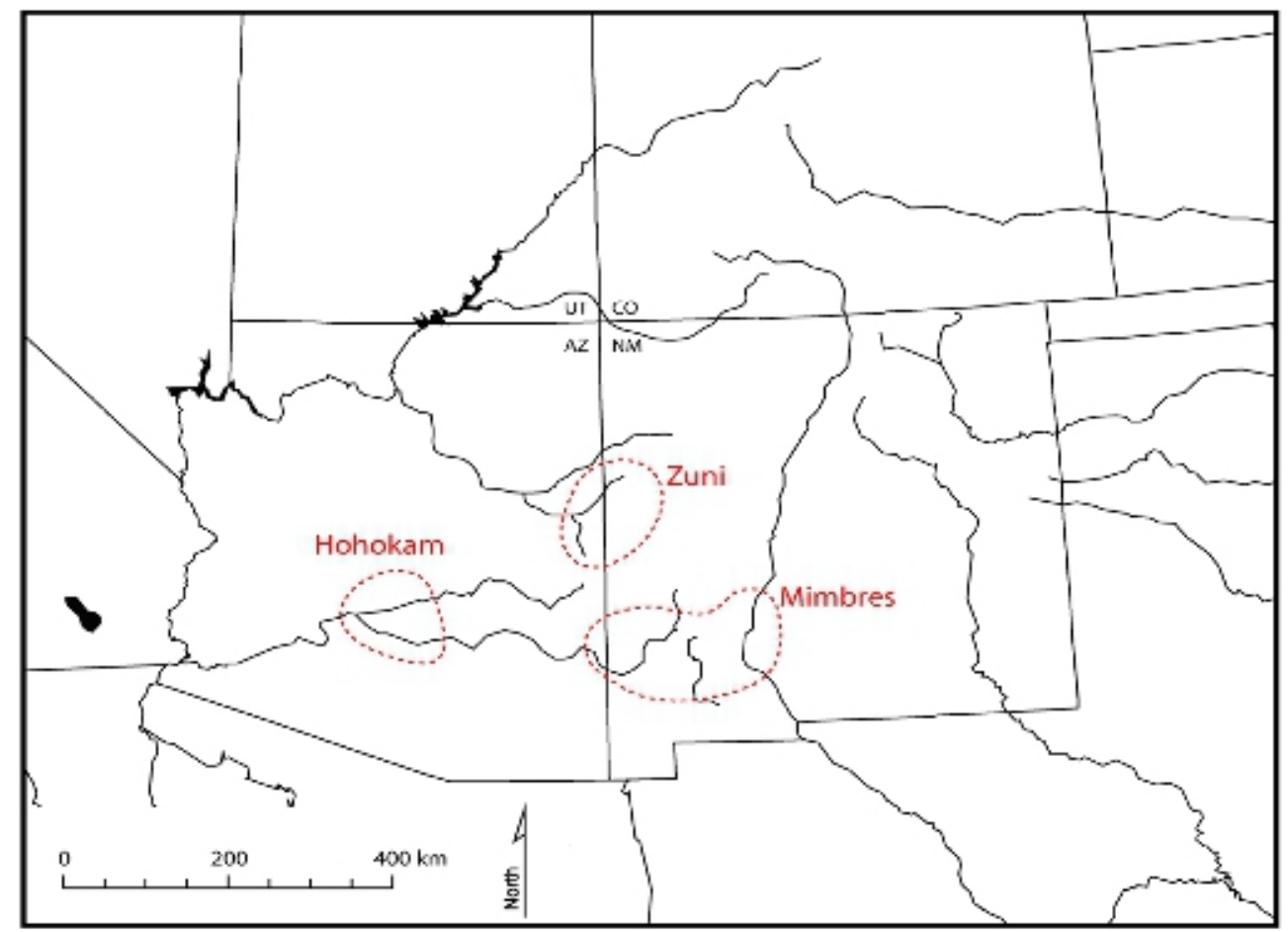

is often used to describe ecosystems and systems in general, robustness and vulnerability are terms that typically describe the response of specific system variables to specific shocks, called "specified resilience" (Walker et al. 2009) in systems with significant human-designed infrastructure. Put another way, we use a robustness-vulnerability framework to explore the relationship between aspects of specified resilience and general resilience (Walker et al. 2009).

Resilience theory suggests that because change is inevitable, a management policy that integrates adaptation to change is preferable to one that manages against change (Folke et al 2002). It has been suggested by some who use resilience concepts to understand change in contemporary and recent historical socioecological systems that efforts to improve the resilience of a system always involve trade-offs. Anderies and others (Scheffer et al. 2001,
Anderies 2006, Anderies et al. 2006, 2007, Janssen et al. 2007) have suggested that resilience, at a particular focal scale, is not an absolute; rather, to understand resilience, one must consider trade-offs between robustness and vulnerability with respect to different classes of uncertainties. In evaluating modern fisheries, as well as pre-Hispanic water control systems for agriculture, Anderies et al. (2007:15194) have found that "policies robust to uncertainty in one group of parameters are necessarily vulnerable to uncertainty in another group." The best we can expect to do is to minimize susceptibility to selected vulnerabilities and attempt to manage for general resilience.

In addition, trade-offs occur among social groups and across temporal and spatial scales. For example, especially in arid environments, water use by one group may create externalities for others. In agricultural systems depending on large canals, 
water use that creates benefits for one user group or individual may result in shortfalls for others. Thus, shared water resources require management or, at least, coordination. However, additional trade-offs occur in the scales of management or control over the water resources. Local users controlling water infrastructure generally have better contextual knowledge of local conditions but may not sufficiently understand the effects of their decisions at the regional scale, depending on the scope and effectiveness of communication and group deliberation (Meinzen-Dick 2007). These facts and observations lead us to a folk theorem of sorts: vulnerability cannot be eliminated from a system; it can only be moved across spatial and temporal scales or across system components. The use of physical and social infrastructure by groups to reduce vulnerability to annual environmental variation introduces new vulnerabilities in the social domain and to events that occur at much larger spatial (basin vs. local) or temporal (annual vs. century) scales. Specifically, the nature of the robustness-vulnerability trade-offs inherent to the types of infrastructure deployed by human groups has important implications for the persistence of those groups and the nature of the transformations they may experience. To evaluate the implications of this folk theorem, we need case studies that span sufficient spatial and temporal scales to observe if and how trade-offs play out. Thus, we investigate three such cases that share similar types (though not scales) of infrastructure, i.e., water management in arid environments, but that played out in different ways.

It is almost universally the case that hunting and gathering strategies in arid and semi-arid environments are quite robust to diverse environmental conditions but can support only very low population densities. In much of the U.S. Southwest, supporting even modest population densities requires a substantial investment in agriculture. Also, in nearly all of the southwestern United States, successful agriculture requires some form of water control to cope with low absolute levels of precipitation and available groundwater, as well as high levels of short-term spatial and temporal variation in precipitation (e.g., Fish and Fish 1984, Dean 1988, Cordell 1997, Spielmann et al. 2010). Here, we focus on trade-offs of robustness and vulnerability created by water control systems that underwrite agriculture, attending to the scales of control and differential advantages for social groups. Different forms of water management can enhance robustness to different sorts of climatic and hydrological conditions. New areas can be made productive and productive areas made more reliably productive with controlled distribution of water. As a consequence, greater numbers of people and concentrations of people can be supported. The extent to which productivity is enhanced, among other things, depends on the form, size, and scale of the physical infrastructure.

We emphasize that the choices that groups make about infrastructure typically involve many direct benefits in the short and medium terms such as greater productivity and the potential to support greater population densities and cultural development. However, with these benefits come subtle trade-offs among different spatial and temporal scales. As such, we are interested not only in the robustness created by water control infrastructure, but also in the potential vulnerabilities associated with this enhanced productivity; we state "potential" because the way in which vulnerabilities play out over the long term depends partly on the dynamic socialecological context and partly on environmental variability and environmental change. We identify three of the many potential vulnerabilities in different domains.

First, the physical infrastructure of water control systems may be vulnerable to rare climatic events, such as major floods or droughts. This is the tradeoff between robustness to low levels of precipitation as well as high-frequency shocks and vulnerability to low frequency shocks, which we refer to as shock frequency. Once the food production system depends on water delivery, the level of production can be disrupted by climatic events. However, the negative effects of major events can be diminished by implementing alternative food production strategies not affected by the same climatic circumstances. Thus, maintaining diverse water control systems or varied farming strategies in different settings, although potentially costly on average, might ameliorate vulnerability to rare climate events.

Second, the commitment to place entailed by physical investments in infrastructure generally increases residential stability or duration of occupation at settlements. In arid settings, local resources such as soils, animals, and plants can be depleted, sometimes permanently, by long-term occupation. In resilience terms, the connection to place can reduce adaptive capacity or response 
capacity. Additionally, for millennia, residential movements were key to the long-term resilience of social-ecological systems across much of the prehistoric U.S. Southwest.

Third, although irrigation systems increase productive capacity, the increasing population and increasing spatial concentration of population into larger villages and towns, which is called aggregation, can challenge or exceed the capacity of local resources, including those enhanced by the water control infrastructure. The slow variable of population increase is traded off against the control over short-term food productivity. However, access to resources through movement and exchange networks can ameliorate this source of vulnerability by redistributing goods and people.

The extent to which these vulnerabilities are realized and may contribute to transformations depends on the social-ecological context and changes in that context over time. We describe the agricultural systems and contexts of three preHispanic cases that can be traced over several centuries. For each case, we look at the trade-offs of robustness and vulnerability attributable to each water control system and the extent to which specific vulnerabilities may have contributed to observed transformations in their specific contexts. By comparing the three cases, we can observe the long-term effects of trade-offs between high- and low-frequency shocks, between fast and slow variables, and in response capacity in different domains.

\section{THE MIMBRES: DITCH IRRIGATION AND SOCIAL REORGANIZATION}

Mimbres refers to an archaeologically defined region in southwest New Mexico of approximately $19,000 \mathrm{~km}^{2}$ (Fig. 2), as well as to the spectacularly decorated pottery made there (Brody 1977, Anyon et al. 1981, LeBlanc 1983, Hegmon 2002). During the period AD 650-1300, gradual change was punctuated in the mid-12th century by a substantial transformation in which the regional population declined and social institutions were reorganized. Less dramatic than the Hohokam case of near total depopulation and collapse of social institutions, including those that supported the irrigation system, people in the Mimbres region reorganized and many remained in the area. We explore robustness and vulnerabilities entailed by water control infrastructure and how these may have played a role in the scale and magnitude of this reorganization.

The subsistence economy of the entire sequence can be characterized as a long period of small-scale farming supplemented by hunting and gathering (Anyon et al. 1981, LeBlanc 1983, Hegmon 2002). Up until AD 1000, settlement remained dispersed, focused regionally around ceremonial structures that were intentionally destroyed in the early 900 s (Creel and Anyon 2003). The subsequent Classic period (AD 1000-1130) was characterized by increased social and technological capitalization, including aggregation of the population into large villages and an inward-focused regional social network (LeBlanc 1983, Hegmon 2002). A reorganization of public ceremony toward focus on smaller ceremonial spaces controlled by specific households within villages accompanied this shift toward larger villages (Clayton 2006).

The end of the Classic period, which coincided with a severe dry period approximately AD 1130, included depopulation of nearly all villages and the virtual disappearance of the famous pottery style (LeBlanc 1983, Nelson and Hegmon 2010). The effects of this sweeping mid-1100s transformation were more dramatic in the densely populated Mimbres Valley, leading to greater depopulation and environmental depletion (Minnis 1985, Sandor 1992, Hegmon et al. 2008) than in the drier and environmentally patchier eastern Mimbres area. Villages were depopulated in part by emigration from the region and in part by dispersion to small settlements within the region (Nelson 1999, Hegmon et al. 2000). However, the basic agricultural, hunting, and gathering subsistence base of these people persisted through this partial depopulation and social reorganization (Nelson and Diehl 1999). Within a half century (approximately AD 1200), the local population, augmented by immigrants from farther north and south, had again aggregated into new villages in the region, some located adjacent to the Classic period villages.

\section{Mimbres agricultural system}

The agricultural system of these prehistoric farmerhunter-gatherers was oriented primarily toward the floodplain of the major rivers and tributary drainages (Herrington 1979, LeBlanc 1983, Minnis 1985, Shafer 2003) and was supplemented with runoff farming on hill slopes and alluvial fans (Sandor 
Fig. 2. Map of the Mimbres area, with landforms and sites.
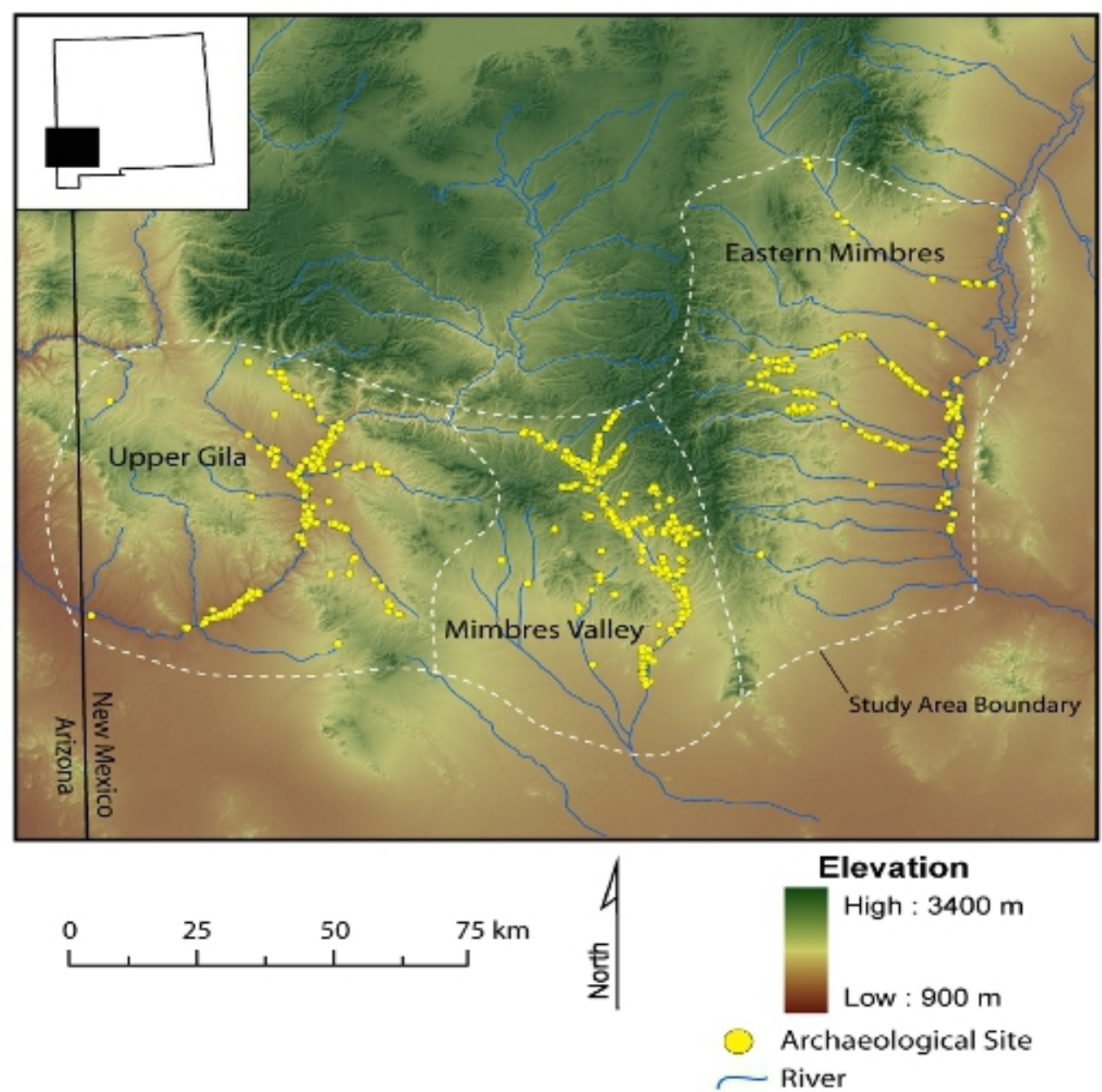

1992). There is limited information on the specific structure of the irrigation system, but we infer from the location of primary fields in riparian floodplains (Minnis 1985) and limited mapping of small ditches that carried water from the rivers (Herrington 1979, Shafer 2003) that the irrigation system consisted of a series of short canals or ditches feeding local floodplain fields. We have no evidence that these were linked in such a way that residents of one village controlled the water flow to the fields of other villages, except that upstream drawdown may have influenced downstream use, especially under conditions of low precipitation (but see the reconstruction by Herrington 1979). This small- scale irrigation system increased the productivity of floodplain fields, as did the stone terracing systems on hill slope and alluvial fan fields, insuring more directed and abundant water and nutrient flow to field locales (Sandor 1992). Increased productivity and potential for food storage increased the robustness of the food supply to localized fluctuations in precipitation. The diversity of field locales and water-directing technologies also improved the robustness of the food supply to the variable spatial distribution of precipitation in the region. 


\section{Trade-offs}

How did these advantages of agricultural productivity and predictability of food supply created by the agricultural infrastructure trade off over the centuries against the potential vulnerabilities associated with such a system? How did these trade-offs contribute to the 12th century transformation? Recall that we have identified three of the potential vulnerabilities as: the effects of rare climate conditions; the effects of place focus on resource degradation and depletion; and the effects of increased capacity to support local population on eventual population-resource imbalance, especially in dry years. The realization of these vulnerabilities is influenced by the changing social context of the Mimbres region.

\section{Potential effects of rare climate conditions (shock frequency trade-off)}

In this region of the U.S. Southwest, declines in precipitation and changes in the temporal and spatial variability of precipitation influence productivity. Water control can ameliorate most high-frequency variation, but rare climatic events can damage this infrastructure. These events may have a greater effect on the food supply when the subsistence economy of farming is focused primarily on the field areas supplied by water control systems: the floodplains of rivers and creeks in the Mimbres region. Severe dry periods reduce the sprouting and growth of cultigens, floods can destroy fields and water control infrastructure, and a lower water table can make irrigation systems dysfunctional.

Climate data are limited to precipitation retrodictions, but these allow us to identify severe dry periods (Dean 1988; Ingram unpublished manuscript on file at the School of Human Evolution and Social Change, Arizona State University, Tempe, Arizona). Ingram (unpublished manuscript) has analyzed dendroclimatological records, from a tree-ring precipitation reconstruction developed by Grissino-Mayer et al. (1997), to identify the extreme low precipitation periods through over a millennium of occupation in the region (Fig. 3). Many periods of severely low precipitation were experienced during the temporal interval discussed here, and most were not associated with social transformations that are evident in the archaeological record. This pattern suggests that the water management infrastructure supported a subsistence system robust to even these extreme dry periods for centuries. However, the extended period of extremely low precipitation around AD 1130 does coincide with the Classic Mimbres village depopulation. Why might it have been a factor at that time and not before or after? The late 11 th and early 12 th century was a time when increased population, place-focused settlement, and limited regional connectivity converged to make this potential vulnerability a reality, contributing to village and some regional depopulation and the end of some social institutions. These social factors are addressed below.

Residential stability and the potential for resource depletion (local focus and reduced response capacity)

In the arid to semi-arid U.S. Southwest during the prehistoric period, depletion of plant and animal resources (Kohler and Matthews 1988, Kohler 1992, Janssen et al. 2003, Nelson and Schollmeyer 2003) and of soils (Sandor 1992) occurred often and arguably contributed to major transformations (Minnis 1985, Janssen et al. 2003), as it has elsewhere in the world (e.g., van der Leeuw 1998, 2005, Kirch 2005, 2007). Our and Sandor's (1992) analyses indicate that with the dense and continuous occupation at some locales, game and soil resources could have been depleted within a few years (Sandor 1992, Nelson and Schollmeyer 2003, Schollmeyer 2009).

Residential stability, which is the long-term and continuous occupation of places (Horne 1993, Rocek 1996, Stone 1996, Nelson 1999), contributes to depletion of wild resources in the areas surrounding settlements. In the U.S. Southwest, settlement shifting, or what archaeologists call residential mobility, was common (e.g., Schlanger and Wilshusen 1993, Nelson 1999, Varien 1999). However, investments in physical infrastructure encourage stability and place-focused settlement, both because of the need to maintain these systems and because of the higher productivity of agricultural fields in these areas. In the Mimbres region, prior to the 11th century, people shifted settlements frequently (Swanson and Diehl 2003, Swanson 2009). By the beginning of the 1100s, a greater place focus emerged, with long-term settlements relatively evenly spaced along the major rivers and tributaries (Blake et al. 1986, Nelson 1999).

Minnis (1985) has documented a depletion of local riparian vegetation during the 11th to early 12 th centuries in the Mimbres Valley, concurrent with 
Fig. 3. Periods of extremely low in precipitation in the Mimbres region. The tree-ring precipitation reconstruction was developed by Grissino-Mayer et al. (1997), with funding from the Legacy Program, Directorate of the Environment, Natural Resources Division, Fort Bliss, Texas. Periods of extremely low precipitation were identified by Ingram (unpublished manuscript) using a nine-year interval running average throughout the duration of the tree-ring precipitation reconstruction (i.e., AD 622-1994). Extreme lows were defined as those intervals in the lowest quartile and decile of the distribution of all nine-year intervals in the reconstruction.

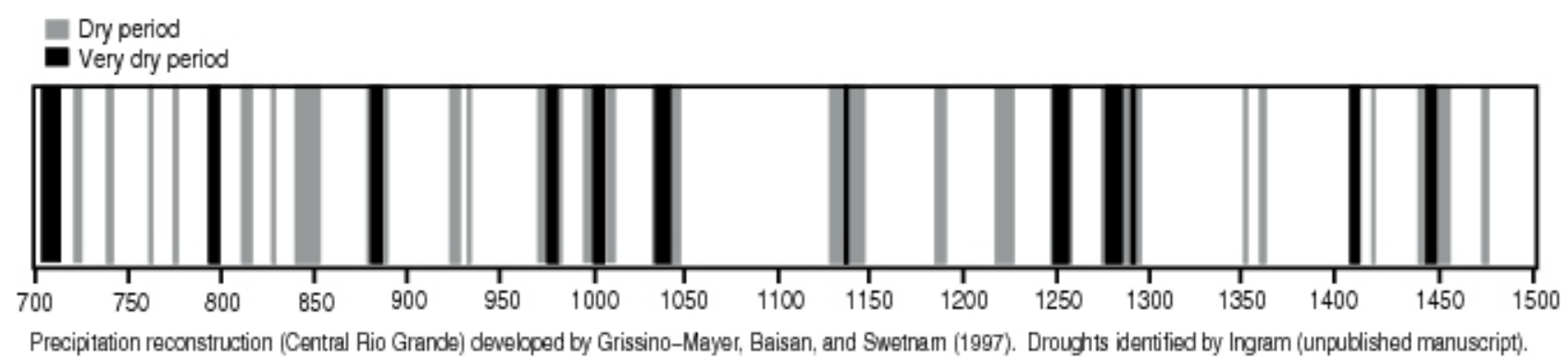

the shift toward residential stability, as land was cleared for fields (Fig. 4); Schollmeyer (2009) has argued that there was also a depletion of game resources. Thus, as residential stability replaced mobility during the 11th and early 12th centuries, the potential for depletion of resources central in the diet of village dwellers was realized. Not only were the plant and animal resources depleted, but soils in secondary fields on upland slopes, made productive with water-directing stone terraces, were also depleted through compaction from repeated use (Sandor 1992). Thus, although the irrigation infrastructure enhanced productivity for agriculture in riparian areas, the stability of settlement in these areas eventually resulted in the decline of plants and animals of this riparian habitat. Also, the creation of fields by terracing upland slopes enhanced their productivity, making farming possible in these settings, but their repeated use resulted in soil decline, which persists to the present day (Sandor 1992).

\section{Potential for population growth and demand on food supply (slow-fast variable trade-off)}

Population size and the concentration of population on the landscape directly influence the potential for food stress, especially in arid and semi-arid landscapes. In the Mimbres region, the population remained dispersed until the 11th century, at which time large, pueblo-style villages were formed. The pattern of population aggregation shows a $75 \%$ increase from the Late Pithouse to the Classic period from 44 settlements to 77 settlements with 50 or more dwellings, which we consider to be aggregated villages (Table 1). This focused settlement pattern, made possible by irrigation infrastructure, increased the demands on local resources. At the same time, the overall regional population increased. The population size changed from the 600 s to the 1400 s, with a peak in the Classic Mimbres period (Fig. 4).

Minnis (1985) has argued that the social, demographic, and environmental conditions of the Classic Mimbres period may have created food stress, at least in the Mimbres Valley. Although available analyses of human remains from Classic Mimbres sites indicate no substantial evidence of poor diet (Lippmeier 1991, Holliday 1996, Gruber 2007), the perception of shortfall or the short-term experience of shortfall can influence decisions to move or reorganize. 
Fig. 4. Change over time in estimated population size and floodplain charcoal from village settlements in the Mimbres region. Population estimates for the Mimbres case are based on a large settlement database compiled as part of the Long Term Vulnerability and Transformation Project. The settlement database includes all sites in major full-coverage surveys across the region, as well as all known large sites (i.e., sites with approximately 30 rooms or more). The population estimates were produced by placing sites in each time period into a number of site size classes based on the best known and recorded components in the database for a particular time period. Sites for which less information was available were placed in size classes based on the available data and were assigned the mean room count of sites in that size class. Following Nelson and Schollmeyer (2003), each 2.5 rooms was assumed to represent one nuclear family household of approximately four individuals. Room-use life estimates were assumed to be roughly 50 years for the purposes of this analysis. The database is likely missing a large proportion of sites dating to the earliest time periods (Early and Late Pithouse periods: AD 400-1000). Thus, population estimates for the earliest periods were defined based on the rates of growth in the best-known portions of the region (Blake et al. 1986).

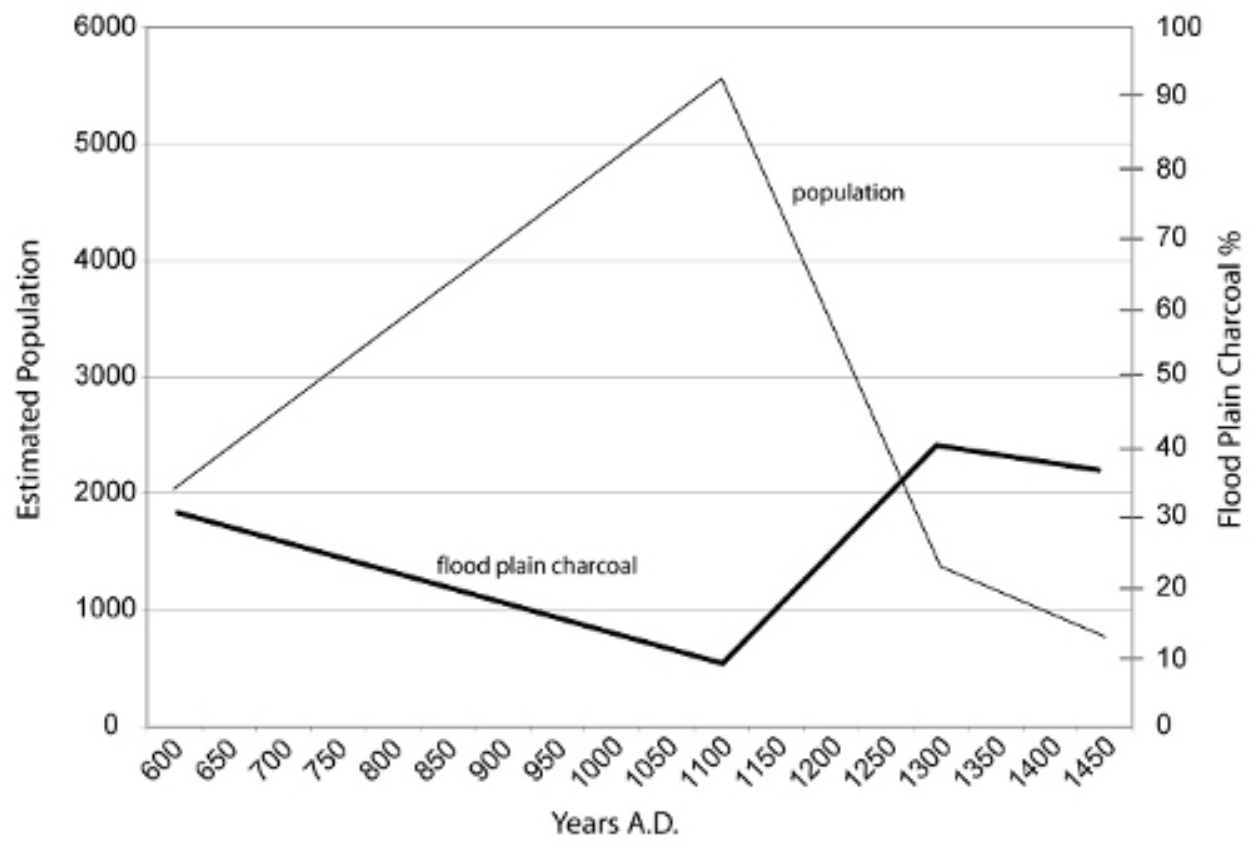

\section{Vulnerabilities and transformation}

Thus, a number of factors coalesced to realize the potential vulnerabilities created by irrigation infrastructure in the 12th century Classic Mimbres period. For nearly a millennium, ditch irrigation had supported a subsistence economy robust to a variable, dry climate. However, the unintended consequences of investing in this system, i.e., residential stability coupled with population increase and resource depletion, eventually contributed to its transformation. The robustness provided by the irrigation infrastructure is evident by the documentation of numerous extreme dry periods throughout the entire sequence that were not associated with village depopulation or migration from the region. On the contrary, people were drawn into the region. The increased population and greater residential stability of the Classic period conspired to make life in Mimbres villages difficult. 
Table 1. Population aggregation patterns in the Mimbres region.

\begin{tabular}{lccccc}
\hline \hline & & \multicolumn{3}{c}{ Number of sites, by room count } \\
\cline { 3 - 5 } Time period & Date range & $<50$ & $50-100$ & $200-300$ & Total \\
\hline Late Pithouse & AD 700-1000 & 94 & 44 & 0 & 138 \\
Classic & AD 1000-1130 & 230 & 66 & 11 & 307 \\
Reorganization & AD 1130-1200 & 16 & 0 & 0 & 16 \\
Early Post Classic & AD 1200-1300 & 40 & 20 & 2 & 62 \\
Late Post Classic & AD 1300-1450 and later & 21 & 14 & 3 & 38 \\
\hline
\end{tabular}

The agricultural systems that had enabled greater populations eventually used the available floodplain field areas, at least in the Mimbres Valley (Minnis 1985), and extended broadly into upland areas to alluvial fans and hill slopes. Those populations declined in the mid-12th century (the end of the Classic period), and many Mimbres traditions ended under extended conditions of low precipitation. Nonetheless, the partial depopulation and social changes in the Mimbres region cannot be attributed entirely to any one factor.

Although the system eventually became vulnerable to low precipitation years, people could have counteracted the low productivity of those years through several social and economic strategies: increasing the use of local wild resources, engaging in extensive exchange, or shifting settlement location. At least two social conditions made these options less likely and increased the vulnerability under the conditions that had developed. The first was an inward focus in social relations; the people of the Mimbres region appear to have engaged in little exchange of goods or people with those of the adjacent and thriving Hohokam and Chaco regional systems (Hegmon and Nelson 2007). Their social boundedness precluded the option of exchange to ameliorate risks of shortfall (Minnis 1985) and may have made movement away from their villages difficult because of a lack of broad-scale social networks. Cross-scale social vulnerabilities combined to contribute to demographic decline and institutional reorganization.
The second condition increasing the vulnerability was the residential stability driven by investments in physical infrastructure, land tenure, and social history. With the depletion of wild resources and removal of land cover brought on by residential stability, the reservoir of productive local plants, animals, and soils was reduced. A series of lowprecipitation years that under other conditions of earlier and later periods (lower population, more extensive exchange, and higher residential mobility) could have been addressed, contributed to the depopulation of nearly all villages in the region and the reorganization of residential communities to a small scale of dispersed hamlets.

Interestingly, it is residential mobility that offered robustness to the changed social and ecological conditions and allowed some people to remain in the region. The end of the Classic period was not a complete collapse or depopulation of the region, as has been documented elsewhere in the U.S. Southwest. Rather, for some who remained in the Mimbres region, there was a regional reorganization marked by a shift from large villages to dispersed hamlets and extensive social networks (Nelson 1999, Nelson et al. 2006), responses that ameliorated some of the vulnerabilities realized in the Classic period system. Change at the village level allowed people to remain in their homeland, maintaining stability at a regional level (Hegmon et al. 1998, Nelson 1999, Nelson and Hegmon 2001, Nelson et al. 2006). This well-studied Reorganization phase following AD 1130 (Hegmon et al. 1998, Nelson 1999) illustrates the processes of release and 
reorganization, known as the alpha and omega phases in resilience theory (Nelson et al. 2006).

Following the Reorganization phase in the mid 13th century, people shifted back into aggregated villages; they abandoned a recognizable Mimbres identity and developed extensive ties to outside areas, resulting in some of the most diverse pottery assemblages known in the U.S. Southwest. With renewed residential mobility and a decline in population, many of the resources depleted during the Classic Mimbres period recovered (Minnis 1985, Schollmeyer 2005). When people eventually re-aggregated, population levels were dramatically lower and effects on local ecosystems were lessened.

The analysis of long-term change in the Mimbres case allows us to track a specific robustnessvulnerability trade-off that may have induced a transformation to a different strategy that moved the system from a local to a regional focus. The robustness-vulnerability characteristics of the Classic period system were simply untenable for the ecology of the Mimbres region. The realization of a vulnerability generated by a strategy aimed at increasing robustness to a specific type of environmental variation engendered a transformation to a new phase of development.

\section{THE ZUNI: SHIFTING AGRICULTURAL STRATEGIES}

The Zuni area, which spans the Arizona-New Mexico border along the southern margin of the Colorado Plateau (Fig. 5), is one of only three areas in the Southwest continuously and densely occupied from the first millennium BC, through the Spanish Conquest, and up to the present day (Ferguson and Hart 1985, Damp 2007). Thus, it is in some sense the most robust of the three cases we examine. Our research focuses on the period $\mathrm{AD} 850$ to 1540 . Excellent, long-term environmental and settlement data and a precise chronological framework enable detailed analyses of long-term changes at generational resolution (e.g., Van West and Grissino-Mayer 2004, Damp 2007, Dean 2007). Until the mid-1200s, settlements were typically geographically dispersed and small, consisting of at most a few families. By AD 900, a few large pit house villages with communal architecture joined these small, dispersed settlements, but disappeared shortly thereafter. During the 11th century, Zuni settlement systems reached their greatest spatial extent (M. Peeples and G. Schachner, unpublished manuscript, http://www.public.asu.edu/ mpeeple/s wsposter.html), exploiting a wide range of local environments across a range of elevations. By the mid-1200s, aggregated upland settlements with as many as 500 rooms appeared. From AD 850 until 1400 , the focus of population generally moved eastward and toward higher elevations, and there was a steady contraction of settled areas (M. Peeples and G. Schachner, unpublished manuscript, http:// www.public.asu.edu/ mpeeple/swsposter.html).

By AD 1300, virtually the entire population appears to have aggregated into villages consisting of single structures with from 150 to perhaps 2000 rooms (Kintigh 1985, 1996, LeBlanc 2001, Kintigh et al. 2004) and located almost exclusively in upland areas, characteristically at $2100 \mathrm{~m}$ elevation. Nonetheless, settlements predating AD 1400 typically lasted from a few years to no more than a generation and never more than a century. Between AD 1350 and 1400, the entire population moved approximately $50 \mathrm{~km}$ downstream, approximately $250 \mathrm{~m}$ lower in elevation, to a few large, long-lasting protohistoric towns along the Zuni River. One, Zuni Pueblo, is still occupied (Stevenson 1905, Kintigh 1985, 2000). Although precise demographic estimates are difficult and data are notably sparse for the period AD 1325-1400, it appears that the population of the Zuni area continued to grow from the earliest times considered here until the middle or late AD 1200s. From that time on, the population probably declined somewhat, but the population density in the occupied area remained high into the historic period (Duff 1998).

\section{Zuni agricultural system}

Direct evidence of Zuni agricultural features is limited, but we can infer quite a bit from the site locations and other available evidence. From AD 850 to $\mathrm{AD} 1250$, the population was widely distributed, but the overall trend was movement from lower to higher elevations. Corn appears in the Zuni area by about 2000 BC (Huber 2005), and small-scale irrigation canals enabled floodplain farming, which has been documented for much of the period between about 1000 BC and AD 1000 (Damp et al. 2002, Damp 2007). The paleoenvironmental data indicate that the period of AD 925-1250 was generally favorable for agriculture in a variety of settings (Dean 2007). 
Fig. 5. Map of the Zuni area, with landforms and sites.

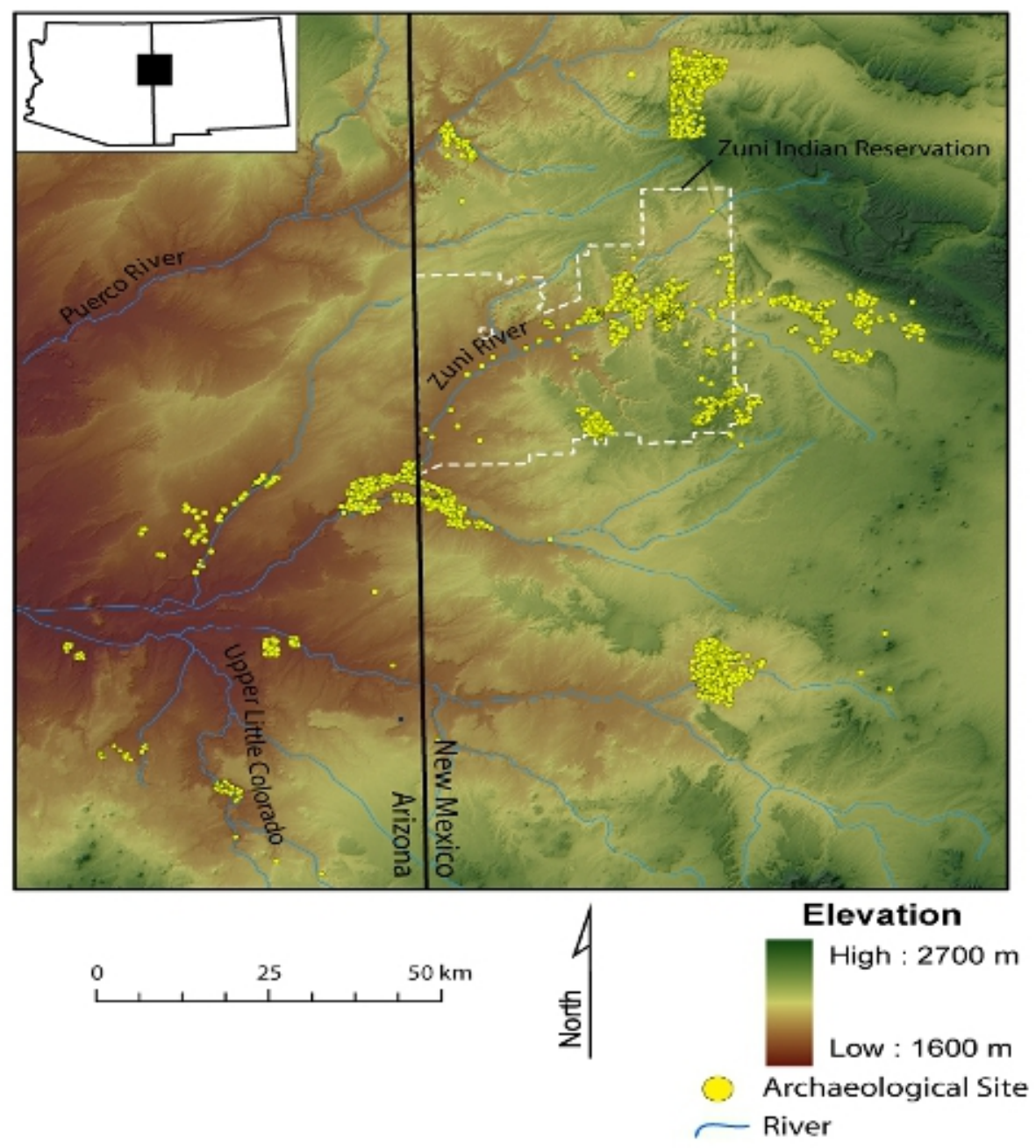

Many of the earlier sites, both large and small, were on duned ridges overlooking areas with substantial floodplains of what are now intermittent streams, suggesting dispersed floodplain and sand-dune agricultural fields watered by groundwater and floodwater, perhaps augmented with runoff (ak chin) farming (Damp 2007). With a lower water table, the period from AD 1250 to 1450 was favorable for runoff farming but disadvantageous for floodplain farming (Damp 2007, Dean 2007). There is some direct evidence of terracing and other forms of runoff farming dating to the beginning of this interval. The AD 1250-1350 preference for runoff farming is also reflected in the settlement patterns, with habitation concentrated in upland areas where appropriate topographic settings for runoff farming were concentrated. After AD 1300, people increased their use of upland settings adjacent to larger springs or other permanent water sources where small-scale irrigation could be practiced in combination with runoff agriculture. The shift to downstream locations of the protohistoric sites between AD 1350 and 1400 was almost entirely to settings on broad floodplains adjacent to the Zuni River or its major tributaries, where runoff farming was not possible. These 
settlements would have required a heavy reliance on irrigation agriculture (Kintigh 1985, 1996).

\section{Trade-offs}

In the Zuni area, how did these advantages of a productive and predictable food supply, enabled by agriculture, trade off with potential vulnerabilities? We again consider the three potential vulnerabilities discussed above: the effects of rare climate conditions; the effects of place focus on resource degradation and depletion; and the effects of increased capacity to support local population on eventual resource stress, especially in dry years.

\section{Potential effects of rare climate conditions (shock frequency trade-off)}

The apparent robustness of the system, including through periods of extremely low precipitation from AD 1120 to 1160 and 1275 to 1300 , is indicative not of a stable adaptation, but of a flexible set of strategies that were employed in response to both high- and low-frequency environmental variability, such as annual spatial and temporal variability in precipitation and hydrological cycles several centuries long (Dean 2007). Thus, as the water table dropped, floodplain settings were abandoned in favor of ones in which runoff agriculture was possible; in longer periods of depressed or increased moisture or temperature, settlements were moved as the elevation-dependent zones having a sufficiently long growing season for maize shifted, expanded, or contracted (Fig. 6).

The AD 1350-1400 shift to locations where irrigation was possible represents a major shift in subsistence strategy. Prior to this, adaptation to short-term variability in precipitation and length of the growing season was probably accomplished, at village and likely household levels, by simultaneous exploitation of topographically diverse settings. Response to long-term shifts in hydrology and the shortening of the growing season was accomplished by moving the settlements. The irrigable locations exploited after AD 1400 were in areas and at elevations that had consistently generous growing seasons. The springs exploited were large and continued to be highly productive through historic droughts (e.g., AD 1945-1964) and probably also during the pre-Hispanic lows of 1350 onward (Fig. $6)$. The towns depending on riverine irrigation exploited the Zuni River, of which the large watershed would have buffered spatial variability in precipitation.

\section{Residential stability and the potential for resource depletion (local focus and reduced response capacity)}

A relatively high population density coupled with a relatively high level settlement mobility characterized the Zuni sequence up until the middle to late AD 1300 s. Villages were typically occupied for less than a generation and in some cases for only a few years (M. S. Thompson, unpublished poster). Soil depletion may help to explain some of the high level of residential mobility that characterized the period from AD 850 to about 1300. The low labor inputs in water control infrastructure would not have substantially deterred mobility over relatively short distances. The historic water control features of the late 1800s, described by Cushing (1979), consisted largely of perishable materials located in settings subject to alluviation. Their construction did not involve large time investments or work by large labor parties, but they needed to be constructed one year prior to their anticipated use. If the prehistoric fields were similarly constructed and located, as seems likely, they would usually be archaeologically invisible, so evidence of this infrastructure is rarely recovered. The limited evidence available suggests that soil depletion may have been a problem in some places but not others. Our investigations of some unusual Zuni area field locations with exposed small artificial terraces on natural mesa terraces indicate compaction and depletion of soil nutrients, as indicated by an absence of modern vegetation 700 years after the end of their use, among other factors. However, in experimental runoff fields in more typical field locations at Zuni, Muenchrath et al. (2002) showed that substantial nutrients and sediments would have been delivered to these runoff fields to replenish them.

After AD 1350-1400, there was much greater commitment to place, as villages were generally occupied for centuries rather than a few decades (Kintigh 1985). There is no direct evidence of the prehistoric irrigation features, in part because many of the best locations have been farmed from then until the present day. Early Spanish accounts indicate that there was canal irrigation at these protohistoric Zuni towns, though the scale and complexity of the irrigation system is not entirely clear (Hodge 1937:67, Wittfogel and Goldfrank 1943, Kintigh 1985:96-97, Damp 2007:123). 
Fig. 6. Periods of extremely low precipitation in Zuni region. Periods of extremely low precipitation were identified by Ingram (unpublished manuscript) using a nine-year interval running average throughout the duration of the tree-ring precipitation reconstruction (i.e., AD 622-1994). Extreme lows were defined as those intervals in the lowest quartile and decile of the distribution of all nine-year intervals in the reconstruction.

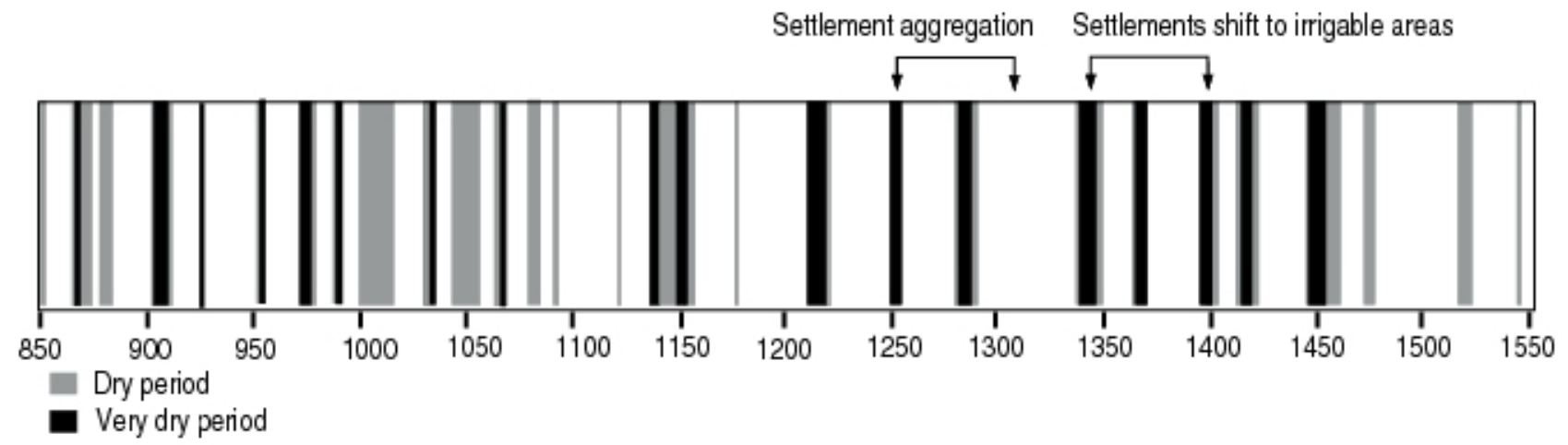

Precipitation reconstruction (Cibola) developed by the Laboratory of Tree-ring Research, University of Arizona (Dean and Robertson, 1978). Droughts identified by Ingram (un published manuscript).

However, the topography and the spacing of the towns along the river suggest that although canals may have served many households, they would have served at most a single town. Whether or not the labor investment in the construction of irrigation facilities exceeded that of the runoff fields considered in the aggregate (as seems likely), it is clear that the maintenance costs would have been much greater and their operation would have required much more coordination at a larger social and spatial scale than the use of runoff fields. This difference suggests an increased commitment to place that is consistent with the very much longer occupation of these towns. We are not aware of scientific studies of the irrigated fields, but modern field locations adjacent to several late prehistoric and protohistoric towns that used the same water sources were intensively farmed in the 19th century (Ferguson and Hart 1985), and some are still productively farmed today, suggesting that soil depletion in at least some locations was not a major problem, even in the long term.

Throughout this sequence, important resources were obtained from hunting and gathering, which doubtless mitigated agricultural shortages (Onken and Van West 2005), though with the population densities experienced in later years, it is likely that both plant and large animal resources such as deer and antelope would have become depleted near the villages. Faunal data indicate that a protein deficiency related to the depletion of large mammals associated with increasingly aggregated settlements may have been offset by raising domesticated turkeys in increasing numbers (Spielmann and Angstadt-Leto 1996).

\section{Potential for population growth and demand on food supply (slow-fast variable trade-off)}

In the absence of much systematic survey, it is difficult to assemble reliable, regional-scale population data because of the temporally variable and spatially patchy distribution of population on the landscape. However, demographic data derived from large, individual, systematic archaeological surveys (e.g., Kintigh et al. 2004, Kintigh 2007) show small initial populations with considerable, if variable, population growth up until a time at which the population dramatically declined (Fig. 7). Both the numbers and average sizes (measured in numbers of rooms) of the settlements increased from approximately AD 850 until 1275 . This pattern is repeated throughout the areas occupied by the 
short-lived settlements that predate AD 1350 (M. Peeples and G. Schachner, unpublished manuscript, http://www.public.asu.edu/ mpeeple/swsposter.html ). Although localized demographic collapses occurred at different times in different places, the data suggest a growing regional population into the 1200s. Because villages dating to this period were relatively dispersed, small, short-lived, and associated with abundant potential field locations, the vulnerabilities to population growth were probably relatively low.

By the late AD 1200s and continuing into the historic period, the regional population was concentrated in a small number of large towns with approximately 150 to 1500 rooms. Archaeologists have probably identified all of these very large villages and have general estimates of their sizes. Prior to the move to downstream locations in the late 1300 s, population concentration would have resulted in increased vulnerability to environmental variability and simultaneously increased the vulnerability to social discord. There would have been limited locations for productive fields within reasonable walking distances of these large towns. A sustained population would have put significant pressure on the resources and fostered competition among households for favorable field locations. An increasing population would have only exacerbated these vulnerabilities.

Although we can estimate the maximal size of the long-lived protohistoric towns (AD 1400-1540), there are no data with which to reconstruct the demographic trends within this period. The archaeological data, combined with early historic accounts, suggest a somewhat lower regional population than in the late prehistoric period (Kintigh 1985). However, these towns were located and intensively used in only a small portion of the region, so the population densities remained high in the area that remained occupied. In contrast to the large, late 13th and early 14th century towns relying on runoff agriculture, in these protohistoric towns, irrigation would have provided much greater productive capacity in proximity to the towns. Relying on the Zuni River and large springs, the irrigated fields would have been buffered from variability in precipitation. In addition, their lower elevation greatly reduced their vulnerability to the abbreviated growing seasons frequently experienced at higher altitudes. If the fields did not significantly degrade and if the population was relatively stable, the vulnerability to environmental change and to social competition may have been limited. However, the villages must have confronted new challenges associated with the management of the irrigation system.

We might ask why it is that these favorable floodplain settings were not intensively used in earlier periods. Part of the answer may lie in the changing floodplain hydrology (Dean 2007). It also may have been due to a lack of social infrastructure to integrate more concentrated populations and to the existence of workable alternatives to relying on floodplain agriculture that did not require social investments. Until the late AD 1300s, the Zuni area had a relatively large population in the aggregate but was relatively insular, with exchange evident only within the region (Duff 2002). Because the overall precipitation and temperature regime was regional in scale, the exchange of food probably would not have been useful in buffering shortfalls caused by major climatic events. However, in the late $1300 \mathrm{~s}$, exchange across regional boundaries increased. Nonetheless, the distances to the nearest other occupied areas would have been large enough, i.e., more than $125 \mathrm{~km}$ to Acoma and nearly $200 \mathrm{~km}$ to Hopi, to call into question whether enough food could have been moved on foot to have a substantial impact (Malville 2001).

\section{Vulnerabilities and transformation}

Prior to the middle AD 1200s, the regional population seems to have maintained a low level of vulnerability to short-term environmental variability, longer-term climatic change, and major climatic events. People avoided this vulnerability through the small sizes of settlements (mostly no more than half a dozen households; Kintigh 1996), their short occupation (a few to perhaps 10 or 20 years; M. S. Thompson, unpublished poster), and the use of lowinvestment, runoff water-control technologies. These conditions suggest a historically and contextually well-informed set of local responses to trade-offs among agriculturally important environmental parameters. The social cost was high mobility, requiring investments in the maintenance of regional networks to facilitate movements, and attendant, repeated investments in new village construction.

From the late $\mathrm{AD} 1100 \mathrm{~s}$, there was increasing aggregation, and by the late $1200 \mathrm{~s}$, the entire population was highly aggregated. This aggregation 
Fig. 7. Change over time in estimated population size in the Zuni region. Population estimates for the Zuni case were not calculated for the region as a whole. Instead, four large full-coverage survey areas were used to illustrate the magnitude of changes occurring through time in specific places. These surveys consist of the Heshotauthla Archaeological Research Project (Kintigh et al. 2004), the Ojo Bonito Archaeology Project (Kintigh 2007), the Fence Lake Coal Mine Survey (Hogan 1985), and the Miller Canyon Archaeological Survey (Kintigh 1980). Sites were placed into temporal categories using the proportions of well-dated ceramic complexes (following Kintigh et al. 2004). Room counts assigned to each temporal interval were converted into population estimates, assuming two people per masonry room. Population estimates were then adjusted to account for the length of each interval, assuming a site-use life of approximately 25 years.

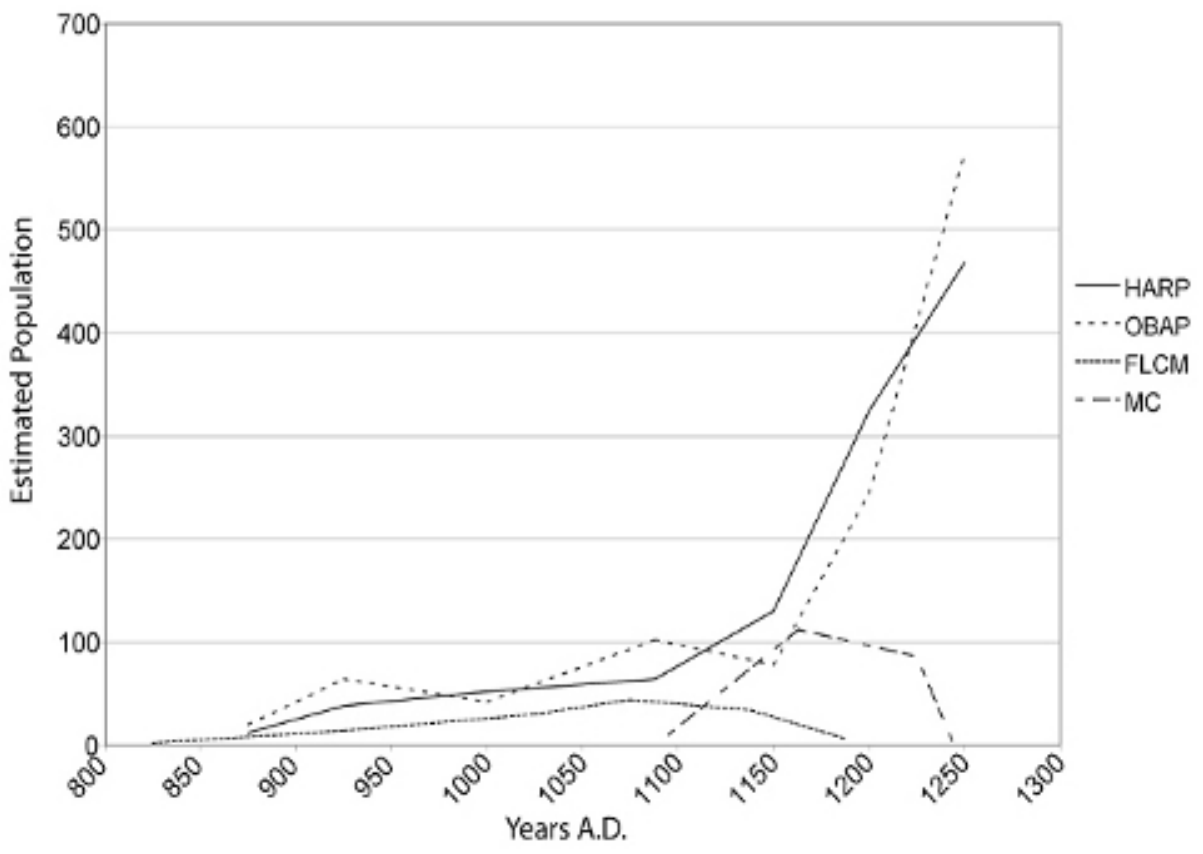

would have necessitated a great increase in the average distance that farmers had to travel to their fields and an increased social cost of integration. Despite the now-higher cost of mobility associated with the large towns, most villages were still shortlived (less than 20 years). However, aggregated settlements reliant on runoff agriculture evidently were not sufficiently robust to withstand the combination of vulnerabilities: social competition for attractive fields, and variability and potential declines in production due to the onset of long-term environmental degradation, including a dropping water table, a more variable climate, and extremely low precipitation from AD 1275 to 1300 .
The increasing aggregation starting in the late $1100 \mathrm{~s}$ would have entailed increasing investment in social infrastructure to deal with the greater levels of competition and conflict inherent in more aggregated social settings. That is, a subsistence strategy evidently robust to high-frequency environmental variability was likely vulnerable to social conflict, though not fatally so, in the context of highly aggregated settlements. In the 11th and early 12 th centuries, the Zuni area was on the southern edge of the Chacoan regional system (Kantner and Kintigh 2006). Kintigh (1994) has argued that the increased aggregation and organizational complexity at that time may have 
been a consequence of the mid-1100s breakup of this regional system into a number of smaller polities competing with one another.

By the late 1300s, regional settlement changed dramatically, with the movement of all villages to lower elevations and the shift to a reliance on irrigation. Movement to lower elevations greatly reduced vulnerability to short growing seasons. The use of water from reliable springs and rivers with large watersheds reduced vulnerability to the spatially patchy rainfall that is associated with runoff fields. This shift was later aided by a rise in water table that ameliorated conditions for floodplain farming at approximately AD 1450 (Dean 2007). The increased productivity per unit area of irrigation agriculture reduced competition for attractive fields. These post AD 1400 settlements were well spaced, perhaps also to minimize resource competition among them. In addition, the social institutions that developed in the 14th century, including the katsina religion (Adams 1992) or Southwestern Cult (Crown 1994), may have mitigated the social vulnerabilities of large towns with populations of several hundred people. Membership in these new social institutions crosscut the strong kinship orientation that must have dominated earlier institutions, greatly increasing social stability within larger population aggregates. As Kroeber (1917:183) observed, "The clans, the fraternities, the priesthoods, the kivas, in a measure the gaming parties, are all dividing agencies. If they coincided, the rifts in the social structure would be deep; by countering each other they cause segmentations which produce an almost marvelous complexity, but can never break the national entity apart." These same integrative institutions may have established a framework on which effective management of an irrigation system could have been based.

The social and demographic continuity in the Zuni case stand in contrast to the depopulation and reorganization of social institutions in the Mimbres case. Mimbres declines resulted from a complexity of factors. The insularity and settlement stability of the Mimbres people allowed all three potential vulnerabilities to be realized. At Zuni, the strategy of changing land use frequently in concert with climate changes allowed an increasing population to remain in the region and social institutions to change gradually, rather than collapse and reorganize as in the Mimbres case.

\section{THE HOHOKAM: INTENSIVE IRRIGATION, FLORESCENCE, AND DECLINE}

The Hohokam region covers a broad area of southern Arizona; we focus on the people who lived along the lower Salt River in what is today the Phoenix metropolitan area (Fig. 8). The prehistoric residents flourished in the valley for a millennium, occupying some of the largest, most densely packed, and longest-lived settlements in the ancient U.S. Southwest. They attained a population size that some estimate at 30,000 (e.g., Earle and Doyel 2008), but whose presence declined to archaeological invisibility by the mid-15th century. Our research spans AD 800-1450, encompassing a major transformation from relative prosperity and an integrated regional system of ceremony and exchange to a collapse of regional networks, and a long and steady slide of population and institutions toward total residential abandonment.

The lower Salt River valley was but one part of the Hohokam interaction sphere. At its height, the Hohokam interaction sphere encompassed 80,000 $\mathrm{km}^{2}$, including the valley lowlands along the lower Salt, middle Gila, and Santa Cruz Rivers, the upland territories to the north, south, and east, and low desert to the west and southwest. Beginning around $\mathrm{AD} 800$, the regional network was integrated by shared ritual beliefs manifest by the playing of a ceremonial ballgame in large earthen courts (Wallace et al. 1995). The regular gatherings of people from many places and a network that interconnected a wide variety of ecological zones made these ballgames conduits through which high volumes of exchange goods moved (Wilcox and Sternberg 1983, Doyel 1991, Wilcox 1999, Abbott et al. 2007b). Wild resources, raw materials, and crafts flowed into the irrigated lowlands from the upland zones, and agricultural surpluses, including cotton and food crops produced with irrigation, probably moved outward from the well-watered valleys to the drier uplands (e.g., Doyel 1991, J. Howard 1993, Shackley 2005, Abbott et al. 2007b). Recent studies of porters worldwide show that foot transport of bulk goods, including foodstuffs, can be expected over distances of $150 \mathrm{~km}$ (Santley and Alexander 1992, Malville 2001), a radius that encompasses most of the Hohokam territory. By AD 1000 , approximately 190 villages held ballcourts (Wilcox et al. 1996, Marshall 2001). 
Fig. 8. Map of the Hohokam area, with landforms and sites.

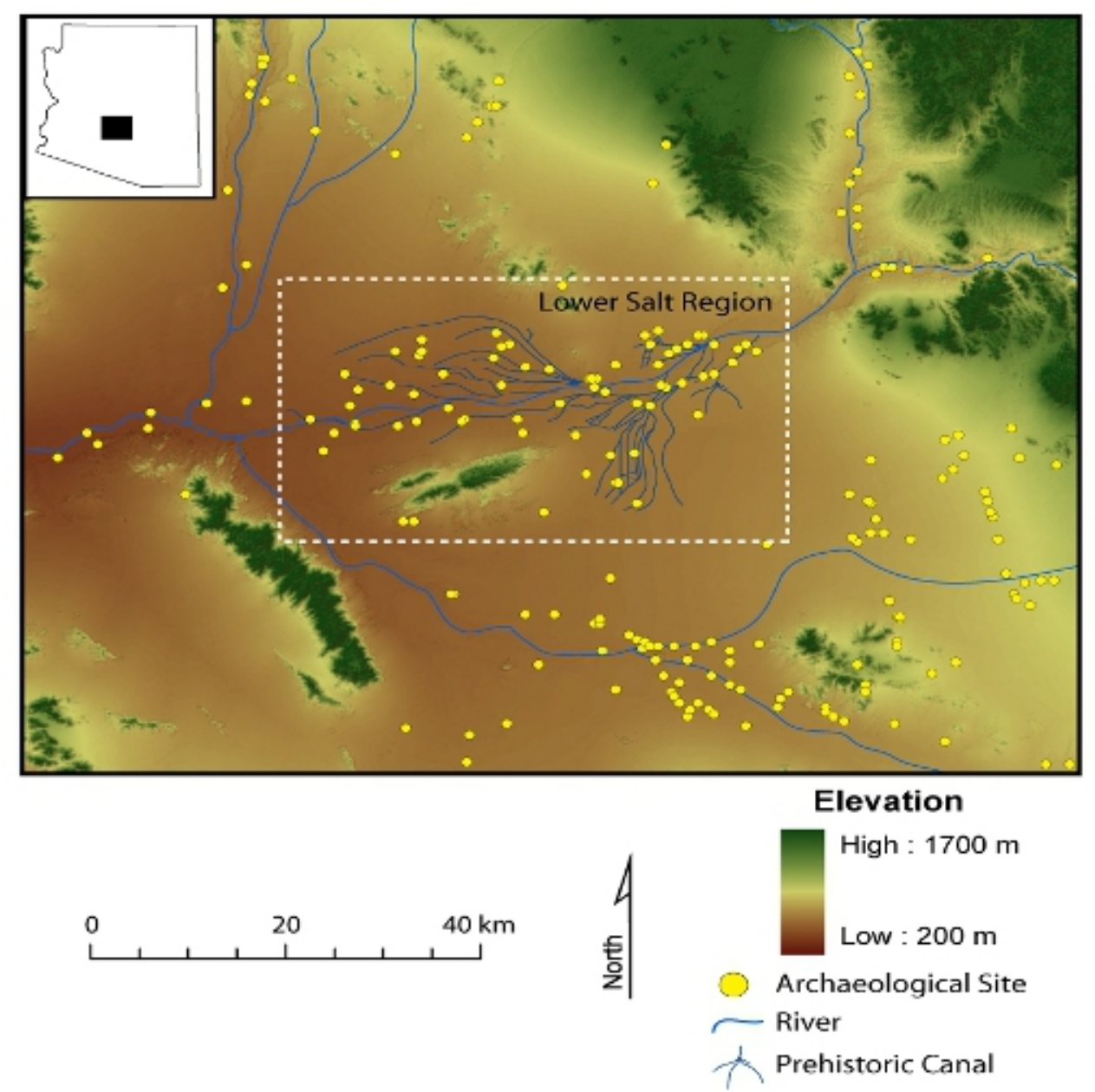

The cultural vigor of shared rituals, widespread cooperation, and high-volume exchange across an expansive region seems to have come to an abrupt halt around AD 1070, when the ballcourt network collapsed (Doelle and Wallace 1991, Doyel 2000, Abbott 2006; but see Wilcox 1991a for a different opinion). Large swaths of the upland zones became depopulated as emigrants streamed into the irrigation-based communities along the major rivers (Doyel 1981, Teague 1984, Wilcox 1991b, Doelle et al. 1995). For instance, at Pueblo Grande, a large and centrally located village along the Salt River, the population rapidly doubled as new immigrant households were established on the outer edge of the settlement (Abbott and Foster 2003). Regional exchange of many kinds of goods was significantly reduced (e.g., Crown 1991), and an intensive focus on local production for local consumption became the norm. Based on the social networks implied by the spatial pattern of transactions expressed by the distribution of ceramic vessels, social fragmentation and territorialism may have taken shape in such a way that social boundaries were coterminous with the irrigation infrastructure (Abbott 2000, 2003b). Local political hierarchies probably emerged, which were associated with the construction and 
ceremonial use of platform mounds, whose access was restricted by massive and towering compound walls, perhaps excluding all but a select few (e.g., Gregory 1991). The local elites may have exerted a degree of ownership over the engineered landscape to extract from it a surplus to finance chiefly institutions (Abbott 2000, Earle and Doyel 2008). However, their political power was largely ineffective for promoting the welfare of their constituents. Increased population pressure, a greater emphasis on agriculture (Kwiatkowski 2003), and over-exploitation of riparian resources (James 2003), led to environmental degradation, declining nutrition, increased disease, and rising mortality rates (Van Gerven and Sheridan 1994, Sheridan 2003). Although occupation in the lower Salt River valley continued into the early 15 th century, the long and steady decline following the collapse of regional networks ultimately led to a total depopulation of a homeland that had been occupied for 70 generations.

\section{Hohokam agricultural system}

The people of the Hohokam region are best known for their irrigation infrastructure, which was the largest network of canals in pre-Columbian North America. More than $500 \mathrm{~km}$ of gravity-fed channels sprawled across the Salt River valley floor in dendritic fashion, where perhaps as much as 650 $\mathrm{km}^{2}$ was brought under cultivation using canal water (Masse 1981:408, Nicholas and Feinman 1989:199, Gregory 1991:171). The desert farmers organized themselves into multi-village irrigation cooperatives to manage their hydraulic works and cultivate crops of corn, beans, squash, and cotton. Each of the cooperatives maintained a set of main canals with a common headgate location, smaller branch and distribution ditches that split from the main lines, and agricultural fields planted along the canal routes. The warm desert temperatures, a generally reliable, predictable, and abundant supply of water in the Salt River, and the expansive acreage of irrigated fields probably provided for two harvests each year (Bohrer 1970). Regular surpluses of cultivated foods and cotton produced for exchange may have been the engine that powered the regional economy.

\section{Trade-offs}

The advantages of the Hohokam irrigation-based economy are evident by the largest and densest populations in the prehistoric U.S. Southwest, which were sustained for centuries (Hill et al. 2004). Ultimately, however, Hohokam society succumbed to wrenching change, eventually leading to total depopulation of the lower Salt River valley. Production at multi-village irrigation cooperatives, situated along the Salt River, was a key component of a much larger regional economy that circulated high volumes of goods (e.g., Doyel 1991, A. Howard 1993, Shackley 2005, Vokes and Gregory 2007), including basic necessities like utilitarian pottery vessels, across the region (Abbott et al. 2007a,b, Abbott 2009). As such, this broad-scale economy was vulnerable not only to direct effects on irrigation management, but also to changing conditions that affected production in other sectors, and pressures on the social networks through which goods were distributed across the region.

As described by Anderies et al. (2004) and Anderies (2006), robustness in one realm is often achieved at the cost of vulnerability in another. In the Hohokam case, the large-scale irrigation technology and its great capacity to supply agricultural surpluses was highly robust to local fluctuations in rainfall, which contributed to the creation of a regional-scale economy. However, it did so with increased vulnerability to social and ecological perturbations at specific localities, which, because of the crosscutting interdependencies, could be felt across the region. Again, we examine three potential vulnerabilities and their influences on transformations in the Hohokam: the effects of rare climate conditions; the effects of place focus on resource degradation and depletion; and the effects of increased capacity to encourage and support the growth of the local populations.

\section{Potential effects of rare climate conditions (shock frequency trade-off)}

Salt River annual discharge is determined by winter precipitation in the upper reaches of the watershed in the White Mountains (Graybill 1989). Flow increases steadily from November to March, reaching a maximum in most years coeval with a critical irrigation interval pertaining to planting of the first corn crop. The river then typically slows to its lowest level in July, coincident with the planting of the second crop (compare Bohrer 1970 and 
Graybill 1989). The intensity of the spring floods probably destroyed diversion weirs and headgates in most years, a circumstance dealt with routinely by Hohokam farmers (e.g., Hunt et al. 2005). Larger floods, however, could bury the upper sections of canals in sediment, requiring considerable repair and possibly the loss of the first crop. Variation in water quantity during the July planting almost certainly affected the extent to which a surplus was produced from the second crop.

At least 1000 years of irrigated agriculture along the Salt suggests the effectiveness of strategies such as storage, food sharing, and exchange to buffer against food shortfalls when climate or other events diminished agricultural production. Extreme climate events in the late 1300 s, however, came at a time when population and associated food requirements were at their peak. Between AD 1356 and 1384, discharge patterns occurred that had not been experienced in over 500 years (Fig. 9). Extreme events during this period included two very high annual flows preceded and followed by low flows that likely magnified the geomorphic effect of these events on the stream channel and associated canal intakes (Graybill et al. 2006:117). These events could have contributed to the long-term slide toward total abandonment.

Earlier climatic events in localities beyond the lower Salt River valley may be more directly implicated in the collapse of the ballcourt network and the regional economy. For instance, some theorists conjecture that down-cutting in the middle Gila riverbed during the 11 th century may have left some canal intakes high and dry, significantly reducing the agricultural outputs along the middle Gila River and the stability of the entire regional economy (Waters and Ravesloot 2000). The efficiencies of complementary production from one ecological setting to the next in the regional system can raise the total productive capacity, but the interdependencies can amplify the effects of local changes, making them felt throughout the region.

Residential stability and the potential for resource depletion (local focus and reduced response capacity)

Cereal growers worldwide typically rely on their cereal crops for about half of their caloric intake (Cordain 1999, Haard et al. 1999). Diet-related evidence indicates that the Salt River inhabitants, who continuously occupied villages for a millennium, supplemented their harvests of corn with bean and squash crops and depended on gathering and hunting local wild resources (e.g., Gasser and Kwiatkowski 1991, Szuter 1991). The regional economy in which they participated also supplied hunted and gathered resources from various ecological zones, and, with the expansion of the regional networks over time, it is likely that the irrigation communities in the lowlands became ever more dependent on nonlocal comestibles until the regional collapse. Prior to the collapse around AD 1070, there were no signs of environmental degradation along the Salt River. However, immediately following that time, the northern uplands overlooking the lower Salt River valley became depopulated, and settlements along the river rapidly swelled with migrants (e.g., Abbott and Foster 2003). The effects on the local wild resource stock were substantial, with severe health consequences for the Salt River populations (Van Gerven and Sheridan 1994, James 2003, Kwiatkowski 2003, Sheridan 2003). Irondeficiency anemia became rampant (Van Gerven and Sheridan 1994), probably related to a disruption of large-game supplies from the upland zone (Abbott 2003a). Greater emphasis was placed on irrigated crops, with a resultant narrowing of the diet (Kwiatkowski 2003), which, unfortunately, happened just prior to the change to a more chaotic streamflow regime in the Salt River. The Salt River Hohokam invested heavily in their irrigation infrastructure to supply a regional market on which they, in turn, depended for vital resources. The interdependencies succeeded in building an efficient and productive regional economy, but at the risk of local perturbations, whose effects could cascade across the system.

\section{Potential for population growth and demand on food supply (slow-fast variable trade-off)}

Steady population growth along the Salt River probably characterized the period between AD 800 and 1350, with rapid decline thereafter (Fig. 10). The sustained agricultural success, however, may have encouraged substantial expansion of the hydraulic infrastructure sometime after AD 1000, at the height of the regional economy. A major irrigation complex, named the Lehi Canal System, was built around AD 1000 upstream of the other irrigation cooperatives on the river (Howard 1987), possibly by a migrant group from the middle Gila River valley to the south (Abbott 1995). The establishment of several new ballcourt villages and 
Fig. 9. Stream flow discharge of the Lower Salt River in the Hohokam region.

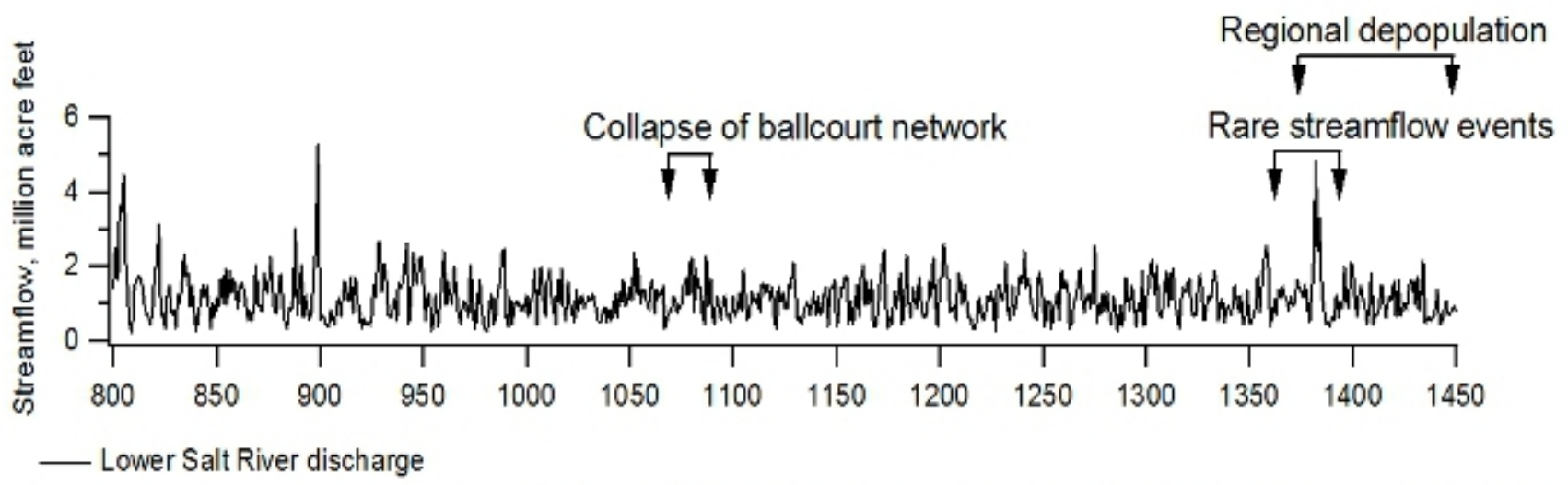

Streamflow reconstruction developed by Graybill et al. $(1989,2006)$ and the Laboratory of Tree-ring Research, University of Arizona

the addition of hundreds of irrigated hectares put new pressures on the water supply, which may have become a limiting resource at that time (J. Howard 1993). Diversion of the river flows by the Lehi farmers may have undercut the capacity of some downstream irrigation cooperatives to grow a surplus of corn and cotton for trade. In effect, the productive output in the valley as a whole after AD 1000 may have reached a maximum, while expanding local populations consumed their share and left a diminishing proportion of the total output for exchange with populations elsewhere in the region.

\section{Vulnerabilities and transformation}

By investing in large-scale irrigation technology, the Hohokam farmers in the lower Salt River valley assured themselves of a goodly supply of cultivated resources. At the same time, their infrastructure investments densely concentrated a large population in a single place, putting their local environment at risk for depletion and degradation. The Salt River inhabitants initially avoided that vulnerability by participating in a vast network of exchange organized around widespread sharing of religious beliefs and periodic ceremonial festivities at ballcourt villages throughout the region. Fostered by a reliable, predictable, and abundant streamflow regime in the Salt River, the irrigation works were probably built to supply a surplus production of food crops and cotton to a regionally integrated economy. If so, the efficiencies of local specialization and the integration of diverse ecological zones, via the ballcourt rituals, underpinned webs of reliable dependencies, but at the risk of hypercoherence whereby local perturbations were felt throughout the region. When interconnections are too strong and too critical, local changes such as rising imbalances between supply and demand, sociopolitical strife that disrupts the movement of goods, and impairments to production capacities can cascade through the regional networks, causing regional-scale social, political, and economic transformation.

Why cultural vitality probably changed to decline around A. D. 1070 remains a key issue for investigation, although several ideas include: overexpansion of the Salt River infrastructure with the construction of the Lehi Canal System (J. Howard 1993, 2006); an unusual down-cutting event in the Gila River that entrenched the channel, dropping the water level below the reach of some canal diversions (Waters and Ravesloot 2000); and political unrest and hostilities at the northern margins of the Hohokam territory that pushed inhabitants out of vulnerable upland areas into the densely occupied lowland communities (Wilcox et al. 2001). Each of these possible events could have disrupted and fragmented the regional economy. 
Fig. 10. Population growth in the Lower Salt River valley of the Hohokam region. Population estimates for the Hohokam region are primarily based on previous work by Doelle $(1995,2000)$, who estimated population by placing all large sites across the region into a number of site size classes and defining a momentary population estimate for each size class based on the best-known examples in each category. He then used the existing information from archaeological surveys across the region to estimate roughly what proportion of the sites in a given time period are likely known. This information was used to create conversion factors that attempt to account for sites missing from the database. We used Doelle's original procedures, but incorporated new information on specific sites and time periods into the database,

altering the previously published estimates. The dotted portion of the line represents a time period for which there are few data. For our purposes, we assumed that the population increased gradually during this time to the levels estimated for the better-known period at around AD 1200.

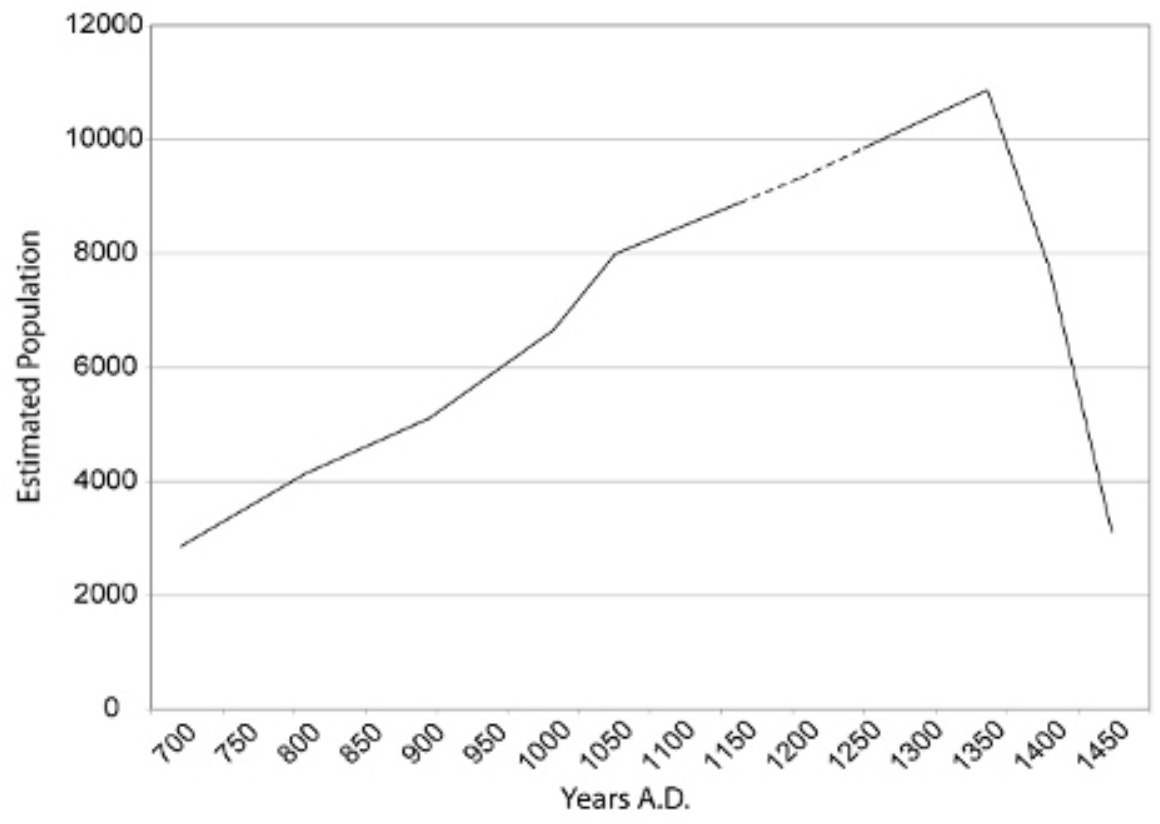

By severing connections to the larger networks after AD 1070 and reducing their exposure to regionalscale vulnerabilities, the irrigation cooperatives along the Salt River probably insulated themselves from external pressures but assumed the risks of going it alone following the collapse of the regional ballcourt network. Local political hierarchies emerged in each of the irrigation cooperatives, possibly taking command of the hydraulic infrastructure, supervising the construction of platform mounds for exclusionary ceremonies, and advocating the social boundaries coterminous with the cooperative's irrigation works (Abbott 2000, Abbott et al. 2006, Earle and Doyel 2008). Under their leadership, agricultural production for local consumption was intensified (Kwiatkowski 2003), presumably to supplement for the loss of wild plant foods and game that had previously been acquired via transactions with external populations, as well as to feed newly arrived immigrants who apparently exercised their kinship options to join the irrigation communities (Abbott and Foster 2003). Although probably not uniformly felt across the valley (Meegan 2009; R. Hill and L. Lincoln-Babb, unpublished presentation), the result for many was a narrowing of the diet, with local habitat imbalances leading to environmental degradation, poor health, and increased mortality (Van Gerven 
and Sheridan 1994, James 2003). Along the Salt River, a protracted and steady decline ultimately concluded when the last Hohokam village in the valley was depopulated.

The Hohokam case contrasts with those of the Mimbres and Zuni in the scale of population and investment in water control infrastructure, among other dimensions. However, simple scale differences do not account for the differences in the trajectory of demographic and social change. For centuries, people in the Hohokam region managed their population increases and settlement stability, in part because of the advantage offered by their broad regional network through which people and resources moved regularly. The Mimbres lack of such a network in the 12 th century contributed to their decline. However, the Zuni apparently thrived, despite the lack of such a network prior to the late AD 1300s. It may be that through the prehistoric period, the Zuni region provided ample opportunities for settlement mobility that were not available to the people of the Hohokam Classic period in the Salt River Valley or the Mimbres Classic period in the Mimbres Valley. And among the Hohokam, as Abbott (2003a) has argued, the collapse of this important regional network began their slow decline. All of the potential vulnerabilities on which we focused here came together to result in the most dramatic population decline in the prehistory of the U.S. Southwest.

\section{LESSONS}

For arid-land farmers, physical infrastructure that captures or directs water for agriculture ameliorates low levels and short-term temporal and spatial variability in precipitation and improves productivity. Increased productivity and potential for food storage improves the robustness of the food supply to localized low precipitation levels and fluctuations in precipitation. The diversity of field locales and water-directing technologies also improves robustness of the food supply to the variable spatial distribution of precipitation in the region. In the cases examined here, new areas were made productive and productive areas were made more reliably productive with controlled distribution of water. As a consequence, greater numbers and concentrations of people were supported, and the systems remained robust to climate changes for centuries.
However, water management infrastructure also creates vulnerabilities to various conditions, even in small-scale systems: these are the effects of rare climate conditions and infrastructure conditions; the effects of place focus on resource degradation and depletion; and the effects of increased capacity to support local population during times of resource stress, especially in dry years. As we have emphasized, all of these are potential vulnerabilities; their effects are context dependent. If the population had not increased as a result of improved productivity, for example, food stress may not have emerged as a vulnerability. Our examination of context over long time sequences addresses the variety of social and behavioral practices associated with physical infrastructure that counteract some potential vulnerabilities or give rise to others. We do not suggest that potential vulnerabilities necessarily were recognized by the people living in these societies or that their social and behavioral practices necessarily were designed or adopted to reduce those vulnerabilities; that is a different analysis. We do suggest that generalizing about vulnerabilities is not productive without an understanding of the social context of a case and a long-term view of how resilience and vulnerability interact.

In the Hohokam case, the physical infrastructure of water control, i.e., an extensive canal network that made intensive maize agriculture possible in the Sonoran desert, was sustained for over a millennium. The infrastructure remained in place through many periods of low and high precipitation. Although people were place focused, they acquired a wide array of resources and maintained access to a variety of resource areas for centuries through an extensive, pan-regional exchange network, which also provided a social environment conducive to maintaining their extensive canal network. Once that extensive social network became fragmented, resources brought from afar were no longer available and the social relations that supported the canal systems changed. With these changes, the potential vulnerabilities were realized: people suffered, institutions collapsed, and the region was depopulated to such a level that the remaining population was not archaeologically visible. In the Mimbres case, investments in infrastructure and a focus on floodplain farming provided a reliable food base that was robust to climate fluctuations. These advantages of floodplain irrigation farming eventually contributed to a place-focused 
residential pattern at primary field areas. This sedentism, one of the vulnerabilities of investments in physical infrastructure, contributed to local depletion of plant and game resources. By AD 1130, the social institutions that supported village life were discontinued, but unlike the Hohokam case, there was no suffering or major institutional collapse. People were able to shift settlements and reorganize their social institutions. Their maizebased economy continued at a smaller scale, but was still reliant on floodplain irrigation infrastructure. Thus, although this technological system contributed to vulnerabilities, its robustness to the variable climate conditions remained important.

Finally, the Zuni case illustrates how social and physical changes together kept potential vulnerabilities from being realized. The water delivery infrastructure in the Zuni region was much smaller scale and more dynamic than that in the Hohokam region, supporting a much smaller population. In Zuni, farming strategies were altered with shifts in climate and population. In addition, unlike the people of the Mimbres Classic period, Zuni villagers did not become place focused, even with considerable investments in physical infrastructure (villages and fields), until the end of the prehistoric sequence when they had developed social mechanisms that reduced factionalism. This cultural group continues into the present, living in the Zuni region.

We are well aware that the fragmentary nature of the archaeological record constrains the detail with which we can reconstruct the social processes that underlie the resilience properties of socialecological systems. Our reliance in archaeology on inferences about dynamics from static material remains and their contexts makes interpretation subject to change as new materials are uncovered, new methods of investigation and analysis are developed, and interpretations are re-examined. However, archaeology allows us to examine the dynamics of SESs on temporal and spatial scales that are otherwise unattainable.

Our comparison of the Mimbres, Zuni, and Hohokam cases illustrates three types of potential resilience-vulnerability trade-offs involving different temporal and spatial scales: annual vs. multidecadal frequency of environmental variation, local vs. regional scale of economic organization, and immediate vs. delayed change in key variables affected by human decisions. For example, humans may act to enhance the robustness of their physiological state on a daily or monthly basis, responding to variation in the productivity of their resources as they experience them throughout an annual cycle. Their very success may lead to increased vulnerability to processes that change much more slowly, e.g., population growth, soil depletion, or rainfall variation with multi-decadal frequencies (e.g., 100-year floods).

The Hohokam in the Salt River valley invested in massive local infrastructure to suppress variation at annual frequencies and increase the productivity of the desert for agriculture. That advantage was achieved and supported a population that grew over several centuries. However, this success generated vulnerabilities to population growth that occurred on a generational timescale and led to the depletion of local resources. In response, the Hohokam developed social infrastructure at the regional scale, i.e., elaborate trade networks, that enabled them to deal successfully with local-scale, high-frequency shocks at the expense of low-frequency, social shocks at a regional scale. However, regional disruptions may have led to population movement into the Salt River valley, re-exposing and exacerbating the vulnerability of local resources. This cascade of vulnerabilities resulted in the most striking and catastrophic transformation of the three cases, causing suffering and massive regional depopulation.

The trade-off between robustness and vulnerability played out differently in the Mimbres and Zuni cases. Through most of the period considered, the water control infrastructure in the Zuni area was small scale, limiting the productivity advantages and robustness of the system to climatic and hydrological changes. Instead, Zuni farmers adjusted to climate changes by moving frequently enough that the inhabitants did not expose themselves to serious resource vulnerability at local spatial scales. However, increased social and resource vulnerability at a local scale must have accompanied the initial regional-scale social shift to highly aggregated settlements. These vulnerabilities also were mitigated by frequent movement, and probably the fissioning and recombining of social groups, until just prior to the historic period, when the social and physical infrastructures were developed to maintain concentrated populations that were highly place based. 
In the Mimbres case, people became focused on local resources, but in a different sequence from the Hohokam. Rather than beginning with a local focus and expanding the scale, they may have had a regional-scale focus that eventually shifted in the Classic period to a local focus. Rather than responding to a local crisis with further local intensification, as the Hohokam did, the people of the Mimbres region may have returned to a regionalscale focus when they reorganized after the depopulation of Classic period villages, avoiding a transformation to the social and health-related disruptions suffered by people in the Hohokam region.

These cases highlight an important message. As societies attempt to cope with variation and vulnerability at particular scales and in particular domains, they must be keenly aware of the tradeoffs between robustness and vulnerability that they are generating at other scales and in other domains. A lack of such awareness is a recipe for a costly and likely unpleasant transformation. Armed with this awareness, people can better weigh the implications of their decisions and attempt to build general resilience to respond if and when potential vulnerabilities are realized.

Responses to this article can be read online at: http://www.ecologyandsociety.org/vol15/iss3/art31/ responses/

\section{Acknowledgments:}

We thank Ben Nelson, Katherine Spielmann, Marco Janssen, Michelle Hegmon, Matthew Peeples, Stephanie Kulow, Cathryn Meegan, Colleen Strawhacker, Scott Ingram, and Michael Merrill for helpful discussions as part of our Biocomplexity Project Team, as well as those individuals and institutions that provided access to data that were incorporated into our synthesis. We gratefully acknowledge financial support for this research from the National Science Foundation through grants SES 0645789 and BCS 0508001.

\section{LITERATURE CITED}

Abbott, D. R. 1995. Detailed ceramic analysis. Pages 57-115 in T. K. Henderson and D. R. Abbott, editors. Archaeology at the head of the Scottsdale canal system, volume 2: studies of artifacts and biological remains. Anthropological Papers Number 95-1. Northland Research, Tempe, Arizona, USA.

Abbott, D. R. 2000. Ceramics and community organization among the Hohokam. University of Arizona Press, Tucson, Arizona, USA.

Abbott, D. R. 2003a. The politics of decline in canal system 2. Pages 201-228 in D. R. Abbot, editor. Centuries of decline during the Hohokam Classic Period at Pueblo Grande. University of Arizona Press, Tucson, Arizona, USA.

Abbott, D. R. 2003b. Ceramics, communities, and irrigation management. Pages 148-165 in D. R. Abbot, editor. Centuries of decline during the Hohokam Classic Period at Pueblo Grande. University of Arizona Press, Tucson, Arizona, USA.

Abbott, D. R. 2006. Hohokam ritual and economic transformation: ceramic evidence from the Phoenix basin, Arizona. North American Archaeologist 27 (4):285-310.

Abbott, D. R. 2009. Extensive and long-term specialization: Hohokam ceramic production in the Phoenix basin, Arizona. American Antiquity $\mathbf{7 4}$ (3):531-557.

Abbott, D. R., and M. S. Foster. 2003. Site structure, chronology, and population. Pages 24-47 in D. R. Abbott, editor. Centuries of decline during the Hohokam Classic Period at Pueblo Grande. University of Arizona Press, Tucson, Arizona, USA.

Abbott, D. R., S. E. Ingram, and B. G. Kober. 2006. Hohokam exchange and Early Classic Period organization in central Arizona: focal villages or linear communities? Journal of Field Archaeology 31(3):285-305.

Abbott, D. R., A. M. Smith, and E. Gallaga. 2007a. Ballcourts and ceramics: the case for Hohokam marketplaces in the Arizona desert. American Antiquity 72(3):461-484. 
Abbott, D. R., J. Watts, and A. D. Lack. $2007 b$. The provenance and concentrated production of Hohokam red-on-buff pottery: implications for an ancient Arizona. Journal of Anthropological Research 63(3):331-358.

Adams, E. C. 1992. The origin and development of the Pueblo Katsina cult. University of Arizona Press, Tucson, Arizona, USA.

Anderies, J. M. 2006. Robustness, institutions, and large-scale change in social-ecological systems: the Hohokam of the Phoenix basin. Journal of Institutional Economics 2(2):133-155.

Anderies, J. M., M. A. Janssen, and E. Ostrom. 2004. A framework to analyze the robustness of social-ecological systems from an institutional perspective. Ecology and Society 9(1): 18. [online] URL: http://www.ecologyandsociety.org/vol9/iss1/ $\underline{\operatorname{art} 18}$

Anderies, J. M., A. A. Rodriguez, M. A. Janssen, and O. Cifdaloz. 2007. Panaceas, uncertainty, and the robust control framework in sustainability science. Proceedings of the National Academy of Sciences 104(39):15194-15199.

Anderies, J. M., B. H. Walker, and A. P. Kinzig. 2006. Fifteen weddings and a funeral: case studies and resilience-based management. Ecology and Society 11(1): 21. [online] URL: http://www.ecolog yandsociety.org/vol11/iss1/art21/.

Anyon, R., P. A. Gilman, and S. A. LeBlanc. 1981. A reevaluation of the Mogollon-Mimbres archaeological sequence. Kiva 46:209-225.

Blake, M., S. A. LeBlanc, and P. E. Minnis. 1986. Changing settlement and population in the Mimbres Valley, SW New Mexico. Journal of Field Archaeology 13(4):439-464.

Bode, H. W. 1945. Network analysis and feedback amplifier design. D. Van Nostrand, Princeton, New Jersey, USA.

Bohrer, V. L. 1970. Ethnobotanical aspects of Snaketown, a Hohokam village in southern Arizona. American Antiquity 35(4):413-430.

Brody, J. J. 1977. Mimbres painted pottery. SAR Press, Santa Fe, New Mexico, USA.
Carpenter, S. R., and W.A. Brock. 2008. Adaptive capacity and traps. Ecology and Society 13(2):40. [online] URL: http://www.ecologyandsociety.org/vol13/ iss $2 / \operatorname{art} 40 /$.

Clayton, S. C. 2006. Ritual and residence: the social implications of Classic Mimbres ceremonial spaces. Kiva 72(1):71-92.

Cordain, L. 1999. Cereal grains: humanity's double-edged sword. World Review of Nutrition and Dietetics 84:19-73.

Cordell, L. S. 1997. Archaeology of the Southwest. Academic Press, San Diego, California, USA.

Creel, D., and R.Anyon. 2003. New interpretations of Mimbres public architecture and space: implications for cultural change. American Antiquity 68(1):67-92.

Crown, P. L. 1991. The role of exchange and interaction in Salt-Gila basin Hohokam prehistory. Pages 383-415 in G. J. Gumerman, editor. Exploring the Hohokam: prehistoric desert peoples of the American Southwest. University of New Mexico Press, Albuquerque, New Mexico, USA.

Crown, P. L. 1994. Ceramics and ideology: Salado polychrome pottery. University of New Mexico Press, Albuquerque, New Mexico, USA.

Cushing, F. H. 1979. Farming: starting a new field. Pages 249-256 in J. Green, editor. Zuñi: selected writings of Frank Hamilton Cushing. University of Nebraska Press, Lincoln, Nebraska, USA.

Damp, J. E. 2007. Zuni emergent agriculture: economic strategies and the origins of Zuni. Pages 118-132 in D. A. Gregory and D. R. Wilcox, editors. Zuni origins: toward a new synthesis of Southwestern archaeology. University of Arizona Press, Tucson, Arizona, USA.

Damp, J. E., S. A. Hall, and S. J. Smith. 2002. Early irrigation on the Colorado Plateau near Zuni Pueblo, New Mexico. American Antiquity 67 (4):665-676.

Dean, J. R. 1988. A model of Anasazi behavioral adaptation. Pages 25-44 in G. J. Gumerman, editor. The Anasazi in a changing environment. Cambridge University Press, Cambridge, UK. 
Dean, J. S. 2007. Zuni-area paleoenvironment. Pages 77-94 in D. A. Gregory and D. R. Wilcox, editors. Zuni origins: toward a new synthesis of Southwestern archaeology. University of Arizona Press, Tucson, Arizona, USA.

Dean, J. S., and W. J. Robinson. 1978. Expanded tree-ring chronologies for the southwestern United States. Chronology Series 3. Laboratory of TreeRing Research, University of Arizona, Tucson, Arizona, USA.

Doelle, W. H. 1995. Tonto basin demography in a regional perspective. Pages 201-226 in M.D. Elson, M. T. Stark, and D. A. Gregory, editors. The Roosevelt community development study: new perspectives on Tonto basin prehistory. Anthropological Research Papers Number 15. Center for Desert Archaeology, Tucson, Arizona, USA.

Doelle, W. H. 2000. Tonto basin demography in a regional perspective. Pages 81-105 in J. S. Dean, editor. Salado. University of New Mexico Press, Albuquerque, New Mexico, USA.

Doelle, W. H., D. A. Gregory, and H. D. Wallace. 1995. Classic Period platform mound systems in southern Arizona. Pages 385-440 in M. D. Elson, M. T. Stark, and D. A. Gregory, editors. The Roosevelt community development study: new perspectives on Tonto basin prehistory. Anthropological Research Papers Number 15. Center for Desert Archaeology, Tucson, Arizona, USA.

Doelle, W. H., and H. D. Wallace. 1991. The changing role of the Tucson basin in the Hohokam regional system. Pages 279-346 in G. J. Gumerman, editor. Exploring the Hohokam: prehistoric desert peoples of the American Southwest. University of New Mexico Press, Albuquerque, New Mexico, USA.

Doyel, D. E. 1981. Late Hohokam prehistory in southern Arizona. Gila Press, Scottsdale, Arizona, USA.

Doyel, D. E. 1991. Hohokam exchange and interaction. Pages 225-252 in P. L. Crown and W. J. Judge, editors. Chaco and Hohokam: prehistoric regional systems in the American Southwest. SAR Press, Santa Fe, New Mexico, USA.

Doyel, D. E. 2000. The Santan phase in the Phoenix basin. Pages 221-244 in D. Doyel, S. K. Fish, and
P. R. Fish, editors. The Hohokam village revisited. Southwestern and Rocky Mountain Division of the American Association for the Advancement of Science, Fort Collins, Colorado, USA.

Duff, A. I. 1998. The process of migration in the late prehistoric Southwest. Pages 31-52 in K. A. Spielmann, editor. Migration and reorganization: the Pueblo IV period in the American Southwest. Anthropological Research Papers 51. Arizona State University, Tempe, Arizona, USA.

Duff,A. I. 2002. Western Pueblo identities: regional interaction, migration, and transformation. University of Arizona Press, Tucson, Arizona, USA.

Earle, T., and D. E. Doyel. 2008. The engineered landscapes of irrigation. Pages 19-46 in L. Cliggett and C. A. Pool, editors. Economies and the transformation of landscape. AltaMira Press, Plymouth, UK.

Ferguson, T. J., and E. R. Hart. 1985. A Zuni atlas. University of Oklahoma Press, Norman, Oklahoma, USA.

Fish, S. K., and P. R. Fish, editors. 1984. Prehistoric agricultural strategies in the Southwest. Arizona State University, Tempe, Arizona, USA.

Folke, C., S. Carpenter, T. Elmqvist, L. Gunderson, C. S. Holling, and B. Walker. 2002. Resilience and sustainable development: building adaptive capacity in a world of transformations. Ambio 31:437-440.

Gasser, R. E., and S. M. Kwiatkowski. 1991. Food for thought: recognizing patterns in Hohokam subsistence. Pages 417-460 in G. J. Gumerman, editor. Exploring the Hohokam: prehistoric desert peoples of the American Southwest. Amerind Foundation New World Studies Series Number 1. University of New Mexico Press, Albuquerque, New Mexico, USA.

Graybill, D. A. 1989. The reconstruction of prehistoric Salt River streamflow. Pages 25-38 in D. A. Graybill, D. A. Gregory, F. L. Nials, S. K. Fish, R. Gasser, C. Miksicek, and C. Szuter, editors. The 1982-1984 excavations at Los Colinas: environment and subsistence. Arizona State Museum, Tucson, Arizona, USA. 
Graybill, D. A., D. A. Gregory, G. S. Funkhouser, and F. L. Nials. 2006. Long-term streamflow reconstructions, river channel morphology, and aboriginal irrigation systems along the Salt and Gila Rivers. Pages 69-123 in D. E. Doyel and J. S. Dean, editors. Environmental change and human adaptation in the ancient American Southwest. University of Utah Press, Salt Lake City, Utah, USA.

Gregory, D. A. 1991. Form and variation in Hohokam settlement patterns. Pages 159-193 in P. L. Crown and W. J. Judge, editors. Chaco and Hohokam: prehistoric regional systems in the American Southwest. SAR Press, Santa Fe, New Mexico, USA.

Grissino-Mayer, H. D., C. H. Baisan, T. W. Swetnam. 1997. A 1,373-year reconstruction of annual precipitation for the southern Rio Grande basin. Final report submitted to the Directorate of Environment of Natural Resources Division, Fort Bliss, Texas, for the Legacy Program. Laboratory of Tree-Ring Research, University of Tucson, Tucson, Arizona, USA. [online] URL: http://web.u tk.edu/ grissino/downloads/Legacy\%20Final\%20Report. pdf.

Gruber, J. L. 2007. Measuring Mimbres populational health status during the Pithouse to Pueblo transition. Thesis. University of Oklahoma, Norman, Oklahoma, USA.

Haard, N. F., S. A. Odunfa, C.-H. Lee, R. Quintero-Ramírez, A. Lorence-Quiñones, and C. Wacher-Radarte. 1999. Fermented cereals. A global perspective. FAO Agricultural Services Bulletin Number 138. FAO, Rome, Italy. [online] URL: http://www.fao.org/docrep/x2184e/x2184e00. htm.

Hegmon, M. 2002. Recent issues in the archaeology of the Mimbres region of the North American Southwest. Journal of Archaeological Research 10 (4):307-357.

Hegmon, M., and M. C. Nelson. 2007. In sync, but barely in touch: relations between the Mimbres region and the Hohokam regional system. Pages 70-96 in A. P. Sullivan and J. M. Bayman, editors. Hinterlands and regional dynamics in the ancient Southwest. University of Arizona Press, Tucson, Arizona, USA.
Hegmon, M., M. C. Nelson, and M. J. Ennes. 2000. Corrugated pottery, technological style, and population movement in the Mimbres Region of the American Southwest. Journal of Anthropological Research 56(2):217-240.

Hegmon, M., M. C. Nelson, and S. M. Ruth. 1998. Abandonment and reorganization in the Mimbres region of the American Southwest. American Anthropologist 100(1):148-162.

Hegmon, M., M. A. Peeples, A. P. Kinzig, S. Kulow, C. M. Meegan, and M. C. Nelson. 2008. Social transformation and its human costs in the prehispanic U.S. Southwest. American Anthropologist 110(3):313-324.

Herrington, L. 1979. Settlement patterns and water control features of the Mimbres Classic Phase, Grant County, New Mexico. Dissertation. University of Texas, Austin, Texas, USA.

Hill, J. B., J. J. Clark, W. H. Doelle, and P. D. Lyons. 2004. Prehistoric demography in the Southwest: migration, coalescence, and Hohokam population decline. American Antiquity 69 (4):689-716.

Hodge, F. W. 1937. History of Hawikuh, New Mexico: one of the so-called cities of Cibola. The Southwest Museum, Los Angeles, California, USA.

Hogan, P. 1985. Prehistoric settlement patterns in west-central New Mexico. OCA/UNM Report Number 185-211. Office of Contract Archaeology, University of New Mexico, Albuquerque, New Mexico, USA.

Holliday, D. Y. 1996. Were some more equal? Diet and health at the NAN Ranch Pueblo, Mimbres Valley, New Mexico. Dissertation. University of Wisconsin, Madison, Wisconsin, USA.

Horne, L. 1993. Occupational and locational instability in arid land settlement. Pages 43-53 in C. M. Cameron and S. A. Tomka, editors. The abandonment of settlements and regions: ethnoarchaeological and archaeological approaches. Cambridge University Press, Cambridge, UK.

Howard, A. V. 1993. Marine shell artifacts and production processes at Shelltown and the Hind site. 
Pages 321-423 in W. S. Marmaduke and R. J. Martynec, editors. Shelltown and the Hind site: $a$ study of two Hohokam craftsman communities in southwestern Arizona. Northland Research, Flagstaff, Arizona, USA.

Howard, J. B. 1987. The Lehi Canal system: organization of a Classic Period irrigation community. Pages 211-221 in D. E. Doyel, editor. The Hohokam village: site structure and organization. Southwestern and Rocky Mountain Division of the American Association for the Advancement of Science, Glenwood Springs, Colorado, USA.

Howard, J. B. 1993. A paleohydraulic approach to examining agricultural intensification in Hohokam irrigation systems. In V. L. Scarborough and B. L. Isaac, editors. Research in economic anthropology. JAI Press, Greenwich, Connecticut, USA.

Howard, J. B. 2006. Hohokam irrigation communities: a study of internal structure, external relationships and sociopolitical complexity. Dissertation. Arizona State University, Tempe, Arizona, USA.

Huber, E. K. 2005. Early maize at the Old Corn site (LA 137258). Pages 36.1-36.33 in E. K. Huber and C. R. Van West, editors. Fence Lake Project: archaeological data recovery in the New Mexico transportation corridor and first five-year permit area, Fence Lake Coal Mine Project, Catron County, New Mexico. Volume 4: synthetic studies and summary. Technical Series 84. SRI Press, Tucson, Arizona, USA.

Hunt, R. C., D. Guillet, D. R. Abbott, J. Bayman, P. Fish, S. Fish, K. Kintigh, and J. A. Neely. 2005. Plausible ethnographic analogies for the social organization of Hohokam canal irrigation. American Antiquity 70(3):433-456.

James, S. R. 2003. Hunting and fishing patterns leading to resource depletion. Pages 70-81 in D. R. Abbott, editor. Centuries of decline during the Hohokam Classic Period at Pueblo Grande. University of Arizona Press, Tucson, Arizona, USA.

Janssen, M. A., J. M. Anderies, and E. Ostrom. 2007. Robustness of social-ecological systems to spatial and temporal variability. Society and Natural Resources 20(4):307-322.
Janssen, M. A., T. A. Kohler, and M. Scheffer. 2003. Sunk-cost effects and vulnerability to collapse in ancient societies. Current Anthropology 44(5):722-728.

Kantner, J. W., and K. W. Kintigh. 2006. The Chaco world. Pages 153-188 in S. H. Lekson, editor. The archaeology of Chaco Canyon: an eleventhcentury Pueblo regional center. SAR Press, Santa $\mathrm{Fe}$, New Mexico, USA.

Kintigh, K. W. 1980. Archaeological clearance investigation of the Miller Canyon Southeastern Boundary Fencing Projects, Zuni Indian Reservation, New Mexico. Zuni Archaeology Program, Pueblo of Zuni, Zuni, New Mexico, USA.

Kintigh, K. W. 1985. Settlement, subsistence, and society in late Zuni prehistory. Anthropological Papers of the University of Arizona Number 44. University of Arizona Press, Tucson, Arizona, USA.

Kintigh, K. W. 1994. Chaco, communal architecture, and Cibolan aggregation. Pages 131-140 in W. H. Wills and R. D. Leonard, editors. The ancient Southwestern community: models and methods for the study of prehistoric social organization. University of New Mexico Press, Albuquerque, New Mexico, USA.

Kintigh, K. W. 1996. The Cibola region in the postChacoan era. Pages 131-144 in M. A. Adler, editor. The prehistoric Pueblo world, A.D. 1150-1350. University of Arizona Press, Tucson, Arizona, USA.

Kintigh, K. W. 2000. Leadership strategies in protohistoric Zuni towns. Pages 95-116 in B. J. Mills, editor. Alternative leadership strategies in the prehispanic Southwest. University of Arizona Press, Tucson, Arizona, USA.

Kintigh, K. W. 2007. Late prehistoric and protohistoric settlement systems in the Zuni area. Pages 361-376 in D. A. Gregory and D. R. Wilcox, editors. Zuni origins: toward a new synthesis of Southwestern archaeology. University of Arizona Press, Tucson, Arizona, USA.

Kintigh, K. W., D. M. Glowacki, and D. L. Huntley. 2004. Long-term settlement history and the emergence of towns in the Zuni area. American Antiquity 69(3):432-456. 
Kirch, P. V. 2005. Archaeology and global change: the holocene record. Annual Review of Environment and Resources 30:409-440.

Kirch, P. V. 2007. Hawaii as a model system for human ecodynamics. American Anthropologist 109 (1):8-26.

Kohler, T. A. 1992. Prehistoric human impact on the environment in the upland North American Southwest. Population and Environment 13 (4):255-268.

Kohler, T. A., and M. H. Matthews. 1988. Longterm Anasazi land use and forest reduction: a case study from southwest Colorado. AmericanAntiquity 53(3):537-564.

Kroeber, A. L. 1917. Zuñi kin and clan. Anthropological Papers of the American Museum of Natural History 18. American Museum of Natural History, New York, New York, USA. [online] URL: http://hdl.handle.net/2246/97.

Kwiatkowski, S. M. 2003. Evidence for subsistence problems. Pages 48-69 in D. R. Abbott, editor. Centuries of decline during the Hohokam Classic Period at Pueblo Grande. University of Arizona Press, Tucson, Arizona, USA.

LeBlanc, S. A. 1983. The Mimbres people, ancient Pueblo painters of the American Southwest. Thames and Hudson, London, UK.

LeBlanc, S. A. 2001. Warfare and aggregation in the El Morro Valley, New Mexico. Pages 19-49 in G. E. Rice and S. A. LeBlanc, editors. Deadly landscapes: case studies in prehistoric Southwestern warfare. University of Utah Press, Salt Lake City, Utah, USA.

Lippmeier, H. S. 1991. A preliminary assessment of the relative health status between Classic and post-Classic populations of southwestern New Mexico. Thesis. State University of New York, Buffalo, New York, USA.

Malville, N. J. 2001. Long-distance transport of bulk goods in the pre-Hispanic American Southwest. Journal of Anthropological Archaeology 20:230-243.

Marshall, J. T. 2001. Hohokam regional ballcourt data. Pages 571-585 in D. B. Craig, editor. The
Grewe Archaeological Research Project, volume 1: project background and feature descriptions. Anthropological Papers Number 99-1. Northland Research, Tempe, Arizona, USA.

Masse, W. B. 1981. Prehistoric irrigation systems in the Salt River Valley, Arizona. Science 214:408-415.

Meegan, C. M. 2009. Nutritional stress and the depopulation of the lower Salt River Valley Hohokam. Dissertation. Arizona State University, Tempe, Arizona, USA.

Meinzen-Dick, R. 2007. Beyond panaceas in water institutions. Proceedings of the National Academy of Sciences 104(39):15200-15205.

Minnis, P.E. 1985. Social adaptation to food stress: a prehistoric Southwestern example. University of Chicago Press, Chicago, Illinois, USA.

Muenchrath, D. A., M. Kuratomi, J. A. Sandor, and J. A. Homburg. 2002. Observational study of maize production systems of Zuni farmers in semiarid New Mexico. Journal of Ethnobiology 22:1-33

Nelson, M. C., editor. 1999. Mimbres during the twelfth century: abandonment, continuity, and reorganization. University of Arizona Press, Tucson, Arizona, USA.

Nelson, M. C., and M. W. Diehl. 1999. Foraging and farming. Pages 142-166 in M. C. Nelson, editor. Mimbres during the twelfth century: abandonment, continuity, and reorganization. University of Arizona Press, Tucson, Arizona, USA.

Nelson, M. C., and M. Hegmon. 2001. Abandonment is not as it seems: an approach to the relationship between site and regional abandonment. American Antiquity 66(2):213-235.

Nelson, M. C. and M. Hegmon. 2010. Mimbres lives and landscapes. SAR Press, Santa Fe, New Mexico, USA.

Nelson, M. C., M. Hegmon, S. Kulow, and K. G. Schollmeyer. 2006. Archaeological and ecological perspectives on reorganization: a case study from the Mimbres region of the U.S. Southwest. American Antiquity 71(3):403-432. 
Nelson, M. C., and K. G. Schollmeyer. 2003. Game resources, social interaction, and the ecological footprint in southwest New Mexico. Journal of Archaeological Method and Theory 10 (2):69-110.

Nicholas, L. M., and G. M. Feinman. 1989. A regional perspective on Hohokam irrigation in the lower Salt River Valley, Arizona. Pages 199-235 in S. Upham, K. G. Lightfoot, and R. A. Jewett, editors. The sociopolitical structure of prehistoric Southwestern societies. Westview Press, Boulder, Colorado, USA.

Onken, J., and C. R. Van West. 2005. Paleoenvironmental reconstruction. Pages 35.1-35.38 in E. K. Huber and C. R. Van West, editors. Fence Lake Project: archaeological data recovery in the New Mexico transportation corridor and first fiveyear permit area, Fence Lake Coal Mine Project, Catron County, New Mexico. Volume 4: synthetic studies and summary. Technical Series 84. SRI Press, Tucson, Arizona, USA.

Ostrom, E., M. A. Janssen, and J. M. Anderies. 2007. Going beyond panaceas. Proceedings of the National Academy of Sciences 104(39):15176-15178.

Rocek, T. R. 1996. Sedentism and mobility in the Southwest. Pages 17-22 in P. R. Fish and J. J. Reid, editors. Interpreting Southwestern diversity: underlying principles and overarching patterns. Anthropological Research Paper 48. Arizona State University, Tempe, Arizona, USA.

Sandor, J.A. 1992. Long-term effects of prehistoric agriculture on soils: examples from New Mexico and Peru. Pages 217-245 in V. T. Holliday, editor. Soils in archaeology: landscape evolution and human occupation. Smithsonian Institution Press, Washington, D.C., USA.

Santley, R. S., and R. T. Alexander. 1992. The political economy of core-periphery systems. Pages 23-49 in E. M. Schortman and P. A. Urban, editors. Resources, power and interregional interaction. Plenum, New York, New York, USA.

Scheffer, M., S. Carpenter, J. A. Foley, C. Folke, and B. Walker. 2001. Catastrophic shifts in ecosystems. Nature 413:591-596.

Schlager, E., W. Blomquist, and S. Y. Tang. 1994. Mobile flows, storage, and self-organized institutions for governing common-pool resource. Land Economics 70(3):294-317.
Schlanger, S. H., and R. H. Wilshusen. 1993. Local abandonments and regional conditions in the North American Southwest. Pages 85-98 in C. M. Cameron and S. A. Tomka, editors. Abandonment of settlements and regions: ethnoarchaeological and archaeological approaches. Cambridge University Press, Cambridge, UK.

Schollmeyer, K. G. 2005. Prehispanic environmental impact in the Mimbres region, southwest New Mexico. Kiva 70(4):375-397.

Schollmeyer, K. G. 2009. Resource stress and settlement pattern change in the eastern Mimbres area, southwest New Mexico. Dissertation. Arizona State University, Tempe, Arizona, USA.

Shackley, M. S. 2005. Obsidian: geology and archaeology in the North American Southwest. University of Arizona Press, Tucson, Arizona, USA.

Shafer, H. J. 2003. Mimbres archaeology at the NAN Ranch Ruin. University of New Mexico Press, Albuquerque, New Mexico, USA.

Sheridan, S. G. 2003. Childhood health as an indicator of biological stress. Pages 82-106 in D. R. Abbott, editor. Centuries of decline during the Hohokam Classic Period at Pueblo Grande. University of Arizona Press, Tucson, Arizona, USA.

Spielmann, K.A., and E. A. Angstadt-Leto. 1996. Hunting, gathering, and health in the prehistoric Southwest. Pages 79-106 in J. Tainter and B. B. Tainter, editors. Evolving complexity and environmental risk in the prehistoric Southwest. Santa Fe Institute Studies in the Science of Complexity 24. Addison-Wesley, Reading, Massachusetts, USA.

Spielmann, K. A., M. C. Nelson, S. Ingram, and M. A. Peeples. 2010. Sustainable subsistence agriculture: the past is present. Ecology and Society, in press.

Stevenson, M. C. 1905. The Zuni Indians: their mythology, esoteric fraternities, and ceremonies. Bureau of American Ethnology Annual Report 23. Government Printing Office, Washington, D.C., USA.

Stone, G. D. 1996. Settlement ecology: the social and spatial organization of Kofyar agriculture. 
University of Arizona Press, Tucson, Arizona, USA.

Swanson, S. 2009. The ecology of early farming: a Mogollon case study. Dissertation. Arizona State University, Tempe, Arizona, USA.

Swanson, S., and M. W. Diehl. 2003. Mimbres pithouse dwellers. Archaeology Southwest 17(4):3.

Szuter, C. R. 1991. Hunting by prehistoric horticulturalists in the American Southwest. Garland Publishing, New York, New York, USA.

Teague, L. S. 1984. The organization of Hohokam economy. Pages 141-154 in L. S. Teague and P. L. Crown, editors. Hohokam archaeology along the Salt-Gila aqueduct, Central Arizona Project, volume 9: synthesis and conclusions. Archaeological Series Number 150. Arizona State Museum, Tucson, Arizona, USA.

van der Leeuw, S. 1998. The Archaeomedes Project: understanding the natural and anthropogenic causes of land degradation and desertification in the Mediterranean. Office for Official Publications of the European Union, Luxembourg, Luxembourg.

van der Leeuw, S. E. 2005. Climate, hydrology, land use, and environmental degradation in the lower Rhone Valley during the Roman period. Comptes Rendus Geoscience 377(1-2):9-27.

Van Gerven, D. P., and S. G. Sheridan, editors. 1994. The Pueblo Grande Project, volume 6: the bioethnography of a Classic Period Hohokam population. Publications in Archaeology Number 20. Soil Systems, Phoenix, Arizona, USA.

Van West, C. R., and H. D. Grissino-Mayer. 2004. Dendroclimatic reconstruction. Pages 33.1-33.129 in C. R. Van West and E. K. Huber, editors. Archaeological data recovery in the New Mexico transportation corridor and first five-year permit area, Fence Lake Coal Mine Project, Catron County, New Mexico. Volume 3: environmental studies. Technical Series 84. SRI Press, Tucson, Arizona, USA.

Varien, M. D. 1999. Sedentism and mobility in a social landscape: Mesa Verde and beyond. University of Arizona Press, Tucson, Arizona, USA.
Vokes, A. W., and D. A. Gregory. 2007. Exchange networks for exotic goods in the Southwest and Zuni's place in them. Pages 318-360 in D. A. Gregory and D. R. Wilcox, editors. Zuni origins: toward a new synthesis of Southwestern archaeology. University of Arizona Press, Tucson, Arizona, USA.

Walker, B. H., N. Abel, J. M. Anderies, and P. Ryan. 2009. Resilience, adaptability, and transformability in the Goulburn-Broken catchment, Australia. Ecology and Society 14(1): 12. [online] URL: http://www.ecologyandsociety.org/vol14/iss1/ $\operatorname{art12/.}$

Wallace, H. D., J. M. Heidke, and W. H. Doelle. 1995. Hohokam origins. Kiva 60:575-618.

Waters, M. R., and J. C. Ravesloot. 2001. Landscape change and the cultural evolution of the Hohokam along the Middle Gila River and other river valleys in south-central Arizona. American Antiquity 66(2):285-299.

Wilcox, D. R. 1991a. The Mesoamerican ballgame in the American Southwest. Pages 101-125 in V. L. Scarborough and D. R. Wilcox, editors. The Mesoamerican ballgame. University of Arizona Press, Tucson, Arizona, USA.

Wilcox, D. R. 1991b. Hohokam social complexity. Pages 253-275 in P. L. Crown and W. J. Judge, editors. Chaco and Hohokam: prehistoric regional systems in the American Southwest. SAR Press, Santa Fe, New Mexico, USA.

Wilcox, D. R. 1999. A peregrine view of macroregional systems in the North American Southwest, A.D. 750-1250. Pages 115-142 in J. Neitzel, editor. Great towns and regional polities. University of New Mexico Press, Albuquerque, New Mexico, USA.

Wilcox, D. R., G. Robertson, Jr., and J. S. Wood. 2001. Antecedents to Perry Mesa: early Pueblo III defensive refuge systems in west-central Arizona. Pages 109-140 in G. E. Rice and S. A. LeBlanc, editors. Deadly landscapes: case studies in prehistoric Southwestern warfare. University of Utah Press, Salt Lake City, Utah, USA.

Wilcox, D. R., T. Samples, D. Keller, and M. Laughner. 1996. The Wagner ballcourt community and other Cohonina sites. Kiva 61:433-456. 
Wilcox, D. R., and C. Sternberg. 1983. Hohokam ball courts and their interpretation. Archaeological Series Number 160. Arizona State Museum, Tucson, Arizona, USA.

Wittfogel K. A., and E. S. Goldfrank. 1943. Some aspects of Pueblo mythology and society. Journal of American Folklore 56:17-30. 